\title{
TRENDS IN MIGRATION TO IRELAND OF NATIONALS OF COUNTRIES WITH VISA LIBERALISATION AGREEMENTS WITH THE EUROPEAN UNION
}

\author{
ANNE SHERIDAN AND SARAH GROARKE
}

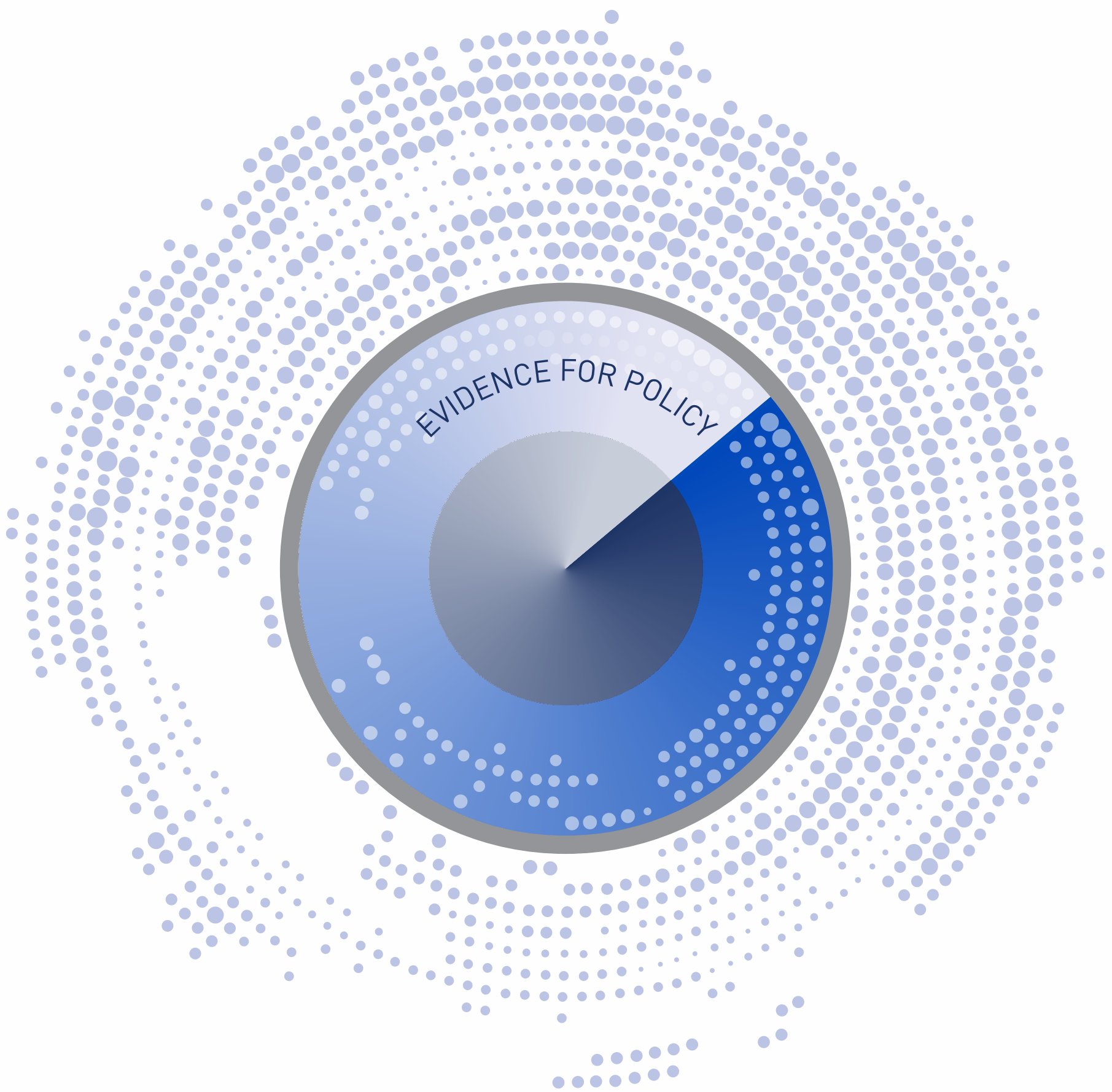





\section{TRENDS IN MIGRATION TO IRELAND OF NATIONALS OF COUNTRIES WITH VISA LIBERALISATION AGREEMENTS WITH THE EUROPEAN UNION}

Anne Sheridan

Sarah Groarke

August 2019

Survey and Statistical Series No: 75

Study completed by the Irish National Contact Point of the European Migration Network (EMN), which is financially supported by the European Union and the Irish Department of Justice and Equality. The EMN was established via Council Decision 2008/381/EC.

Available to download from www.emn.ie

(c) The Economic and Social Research Institute

Whitaker Square, Sir John Rogerson's Quay, Dublin 2

ISBN: 978-0-7070-0497-6

DOI: https://doi.org/10.26504/sustat75

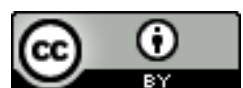

This Open Access work is licensed under a Creative Commons Attribution 4.0 International License, which permits unrestricted use, distribution, and reproduction in any medium, provided the original work is properly credited. 


\section{THE EUROPEAN MIGRATION NETWORK}

The aim of the European Migration Network (EMN) is to provide up-to-date, objective, reliable and comparable information on migration and asylum at Member State and EU levels with a view to supporting policymaking and informing the general public.

The Irish National Contact Point of the European Migration Network, EMN Ireland, sits within the Economic and Social Research Institute (ESRI).

\section{ABOUT THE ESRI}

The mission of the Economic and Social Research Institute is to advance evidencebased policymaking that supports economic sustainability and social progress in Ireland. ESRI researchers apply the highest standards of academic excellence to challenges facing policymakers, focusing on 12 areas of critical importance to 21st Century Ireland.

The Institute was founded in 1960 by a group of senior civil servants led by Dr T.K. Whitaker, who identified the need for independent and in-depth research analysis to provide a robust evidence base for policymaking in Ireland.

Since then, the Institute has remained committed to independent research and its work is free of any expressed ideology or political position. The Institute publishes all research reaching the appropriate academic standard, irrespective of its findings or who funds the research.

The quality of its research output is guaranteed by a rigorous peer review process. ESRI researchers are experts in their fields and are committed to producing work that meets the highest academic standards and practices.

The work of the Institute is disseminated widely in books, journal articles and reports. ESRI publications are available to download, free of charge, from its website. Additionally, ESRI staff communicate research findings at regular conferences and seminars.

The ESRI is a company limited by guarantee, answerable to its members and governed by a Council, comprising 14 members who represent a cross-section of ESRI members from academia, civil services, state agencies, businesses and civil society. The Institute receives an annual grant-in-aid from the Department of Public Expenditure and Reform to support the scientific and public interest elements of the Institute's activities; the grant accounted for an average of 30 per cent of the Institute's income over the lifetime of the last Research Strategy. The remaining funding comes from research programmes supported by government departments and agencies, public bodies and competitive research programmes. Further information is available at www.esri.ie. 


\section{THE AUTHORS}

Anne Sheridan is Senior Policy Officer at the Irish National Contact Point of the European Migration Network (EMN Ireland) at the Economic and Social Research Institute (ESRI). Sarah Groarke is Policy Officer at EMN Ireland.

\section{ACKNOWLEDGMENTS}

We would like to acknowledge the assistance of staff of the Irish Naturalisation and Immigration Service and International Protection Office, who provided data and written comments for Ireland's national contribution to the EMN study, Impact of visa liberalisation on countries of destination, which have been used in this report. We would also like to acknowledge the comments and assistance of our colleagues at EMN Ireland and the ESRI (Emma Quinn, Elaine Byrne, Róisín Dunbar and Sarah Burns) and the comments of the reviewers.

\section{ABOUT THIS REPORT}

This European Migration Network study looks at trends in migration to Ireland from certain countries in the Western Balkans and from certain Eastern Partnership countries that have agreed visa liberalisation agreements with the European Union over the period 2009-2017. The visa liberalisation agreements in place for these countries allow short-stay visa-free travel to the Schengen Area for holders of biometric passports. While Ireland is not part of the Schengen Area, the report sets out trends in migration to Ireland of nationals from these countries. The report consists of information gathered by way of a common template, for an overview, EU-level synthesis report: Impact of visa liberalisation on countries of destination.

This report has been accepted for publication by the Institute, which does not itself take institutional policy positions. All ESRI Research Series reports are peer reviewed prior to publication. The authors are solely responsible for the content and the views expressed do not represent the position of the Economic and Social Research Institute, the Irish Naturalisation and Immigration Service, the Department of Justice and Equality, or the European Commission, Directorate-General Migration and Home Affairs. 



\section{TABLE OF CONTENTS}

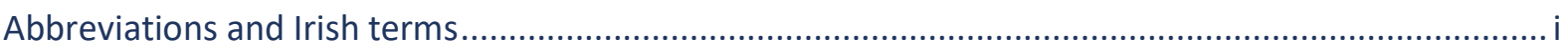

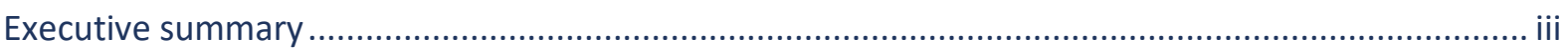

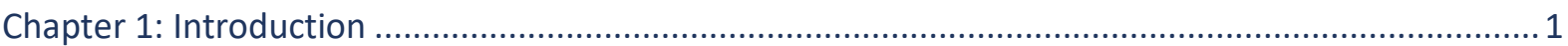

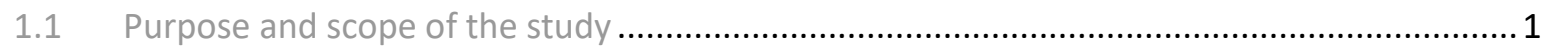

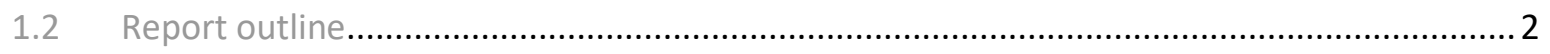

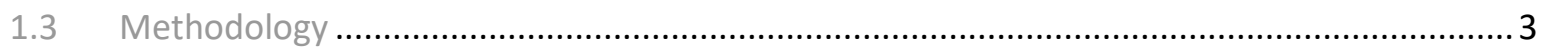

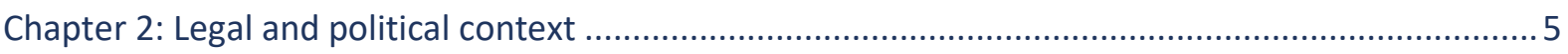

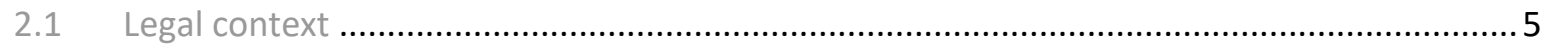

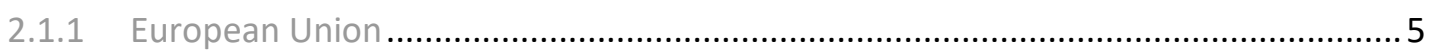

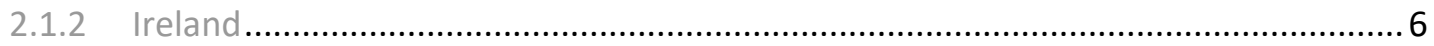

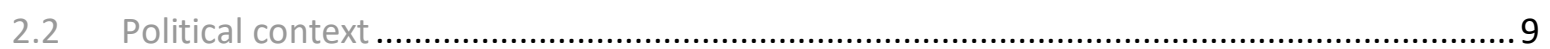

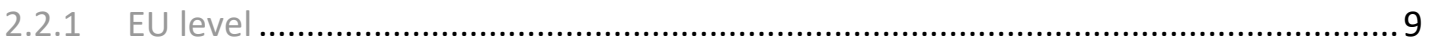

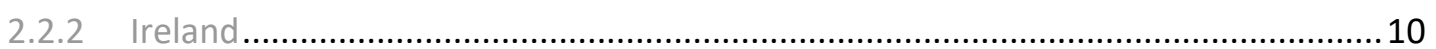

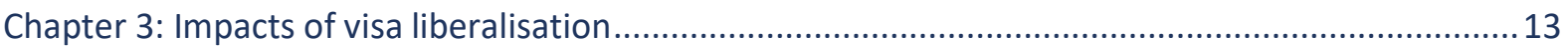

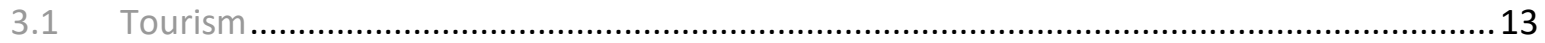

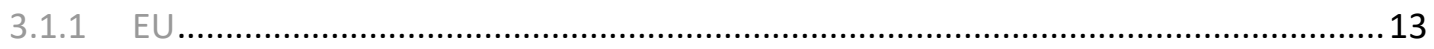

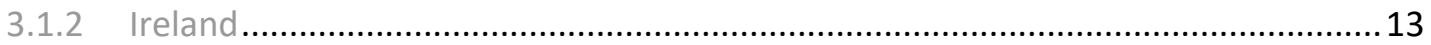

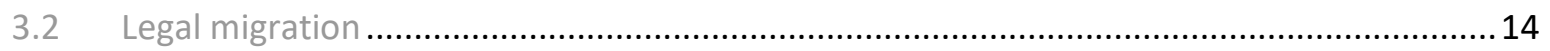

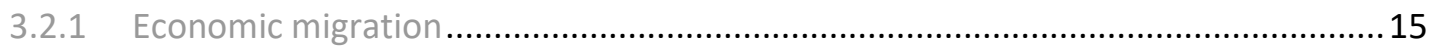

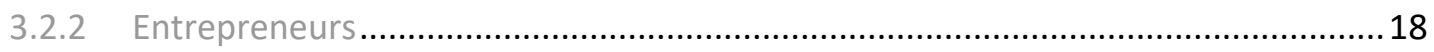

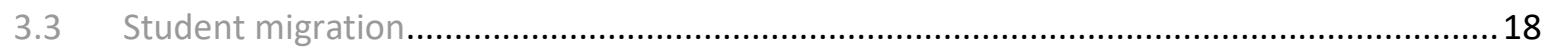

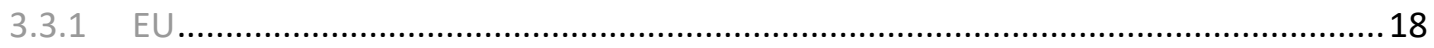

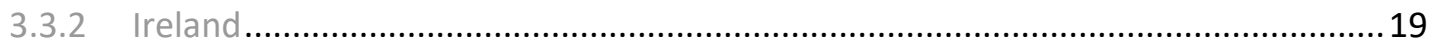

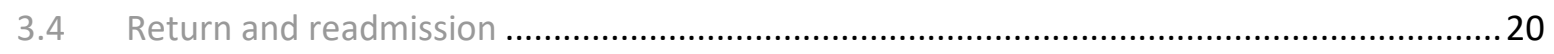

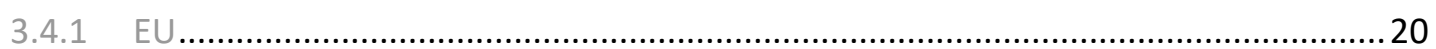

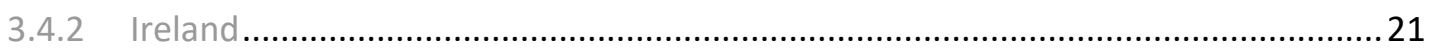

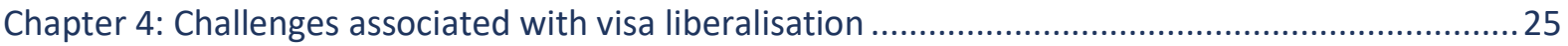

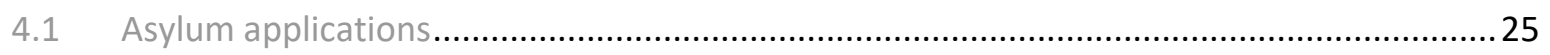

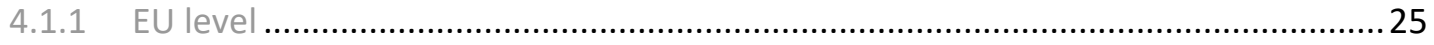

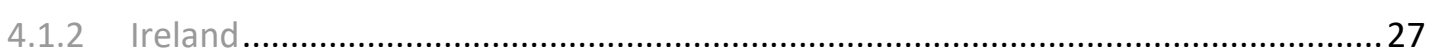

4.1.3 Policy measures taken by Member States in response to increase in asylum

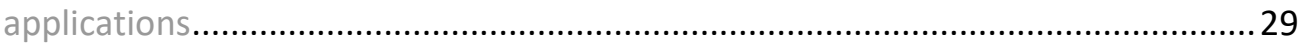

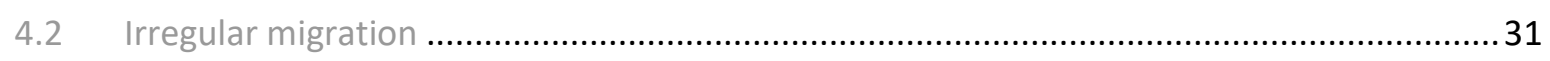

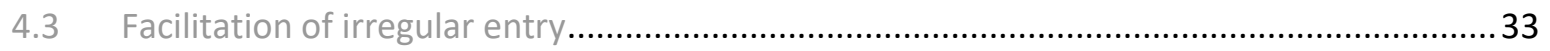

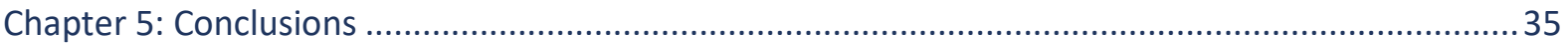

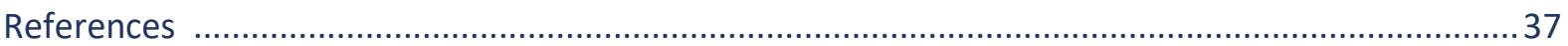




\section{LIST OF TABLES}

Table 2.1 Visa requirements in Ireland for nationals of countries covered by the study 7

Table 3.1 First-residence permits issued in the EU and Norway to nationals of countries within the scope of the study (excluding Ireland and UK), 2008-2017

Table 3.2 First-residence permits issued in Ireland for remunerated activities to nationals of countries within the scope of the study, 2008-2017

Table 3.3 First-residence permits issued for education reasons in the EU and Norway to nationals of countries within the scope of the study (excluding Ireland and the UK), 2008-2017.19

Table 3.4 First-residence permits issued in Ireland for education reasons to nationals of countries within the scope of the study, 2008-2017 20

Table 3.5 Return decisions issued in Ireland to nationals from countries within the scope of the study, 2008-2017.

Table 3.6 Forced returns from Ireland of nationals of countries within the scope of the study, 2012-2017

Table 3.7 Voluntary returns (including assisted) from Ireland by nationals of countries within the scope of the study, 2012-2017

Table 4.1 Asylum applications received in the EU and Norway from nationals of countries within the scope of the study, 2008-2017.

Table 4.2 Asylum/international protection applications received in Ireland from nationals of countries within the scope of the study, 2008-2017

Table 4.3 Nationals of countries within the scope of the study refused entry at the Irish external borders, 2008-2017 


\section{ABBREVIATIONS AND IRISH TERMS}

$\begin{array}{ll}\text { CSO } & \text { Central Statistics Office } \\ \text { EaP } & \text { Eastern Partnership } \\ \text { EC } & \text { European Commission } \\ \text { EEA } & \text { European Economic Area } \\ \text { EFTA } & \text { European Free Trade Association } \\ \text { EMN } & \text { European Migration Network } \\ \text { EU } & \text { European Union } \\ \text { FYROM } & \text { Former Yugoslav Republic of Macedonia* } \\ \text { GNIB } & \text { Garda National Immigration Bureau } \\ \text { IIP } & \text { Immigrant Investor Programme } \\ \text { INIS } & \text { Irish Naturalisation and Immigration Service } \\ \text { IOM } & \text { International Organization for Migration } \\ \text { IPO } & \text { International Protection Office } \\ \text { Oireachtas } & \text { Irish Parliament } \\ \text { PSNI } & \text { Police Service of Northern Ireland } \\ \text { RNM } & \text { Republic of North Macedonia } \\ \text { STEP } & \text { Start-up Entrepreneur Programme } \\ \text { TCN } & \text { Third-country national } \\ \text { UAE } & \text { United Arab Emirates } \\ \text { UK } & \text { United Kingdom } \\ \end{array}$

* On 14 February 2019, the official name of this country was changed to the Republic of North Macedonia. 

The EU's common visa policy is a cornerstone of the way in which it controls the entry of third-country nationals (TCN) into the Schengen Area. The border-free Schengen Area comprises 22 Member States of the European Union and the four European Free Trade Association (EFTA) countries. ${ }^{1}$ Nationals of certain third countries are required to obtain a Schengen visa in order to enter and stay in the Schengen Area for short stays. A holder of a Schengen visa may move freely in the Schengen Area. The European Union agreed visa liberalisation agreements with certain Western Balkan countries and certain Eastern Partnership (EaP) countries over the period 2009-2017. ${ }^{2}$

The European Migration Network's (EMN) EU-wide study, Impact of visa liberalisation on countries of destination, sought to assess the impact of visa liberalisation on migration from nationals of the above-mentioned countries to the EU (EMN, 2019). This report is based on the Irish contribution to the EMN study. As Ireland is not part of the Schengen Area and does not participate in the EU's common visa policy, it seeks to provide a parallel overview of trends in migration to Ireland of nationals of the countries concerned, in circumstances where there is no visa waiver for these nationals to travel to Ireland. It looks at whether or not any link can be adduced between visa-free travel in the Schengen Area and migratory trends towards Ireland from these countries.

The Western Balkans countries covered in this study are Albania, Bosnia and Herzegovina, Montenegro, the Republic of North Macedonia (RNM) and Serbia. ${ }^{3}$ The EaP countries are Georgia, Moldova and Ukraine. The visa liberalisation agreements in place for these countries allow short-stay visa-free travel (90 out of 180 days) to the Schengen Area for holders of biometric passports.

The visa liberalisation agreements are the culmination of visa liberalisation dialogues with the countries concerned, where the countries were required to reach certain benchmarks, in order for the visa liberalisation agreement to be concluded (EMN, 2019). These included: document security including biometrics;

1 The four EFTA states are Iceland, Liechtenstein Norway and Switzerland. Ireland and the UK are not part of the Schengen Area and are therefore not bound by the relevant provisions of the Schengen acquis. Four other EU Member States - Bulgaria, Croatia, Cyprus and Romania - are not yet part of the Schengen Area and do not fully apply the Schengen acquis.

2 The EaP is a joint policy initiative which aims to deepen and strengthen relations between the EU, its Member States and its six Eastern neighbours: Armenia, Azerbaijan, Belarus, Georgia, Moldova and Ukraine. See: European Commission, 'Eastern Partnership', available at https://ec.europa.eu/home-affairs/what-we-do/policies/international-affairs/eastern-partnership_en.

3 On 14 February 2019, the country formerly known as FYROM changed its name to the Republic of North Macedonia - see www.un.org. It was still known as the Former Yugoslav Republic of Macedonia (FYROM) during the period under review for this study. 
border management, migration and asylum (including the signing of readmission agreements with the EU); ${ }^{4}$ public order and security; and external relations and fundamental rights. Visa-free travel brings benefits to nationals of the countries concerned and encourages ties with Europe (European Commission, 2017). For example, in the case of Georgia, the Minister of Foreign Affairs of Georgia remarked, 'Removing visa requirements for Georgian citizens will mean more tourism, cultural and student exchanges, and civil society partnerships. This will help develop Georgia and anchor the next generations firmly within the European family of nations' (Beruchashvili, 2015).

The research for the EU-wide study sought to assess whether or not direct impacts or correlative effects on countries of destination could be attributed to the introduction of visa-free travel to the Schengen Area for nationals of certain countries from the Western Balkans and EaP. The types of benefits assessed included impacts on tourism, trade, and flows of workers and students towards the EU. Challenges for destination Schengen states, including increases in irregular migration, increases in asylum applications and possible misuse of visa liberalisation, were also considered (EMN, 2019).

The synthesis report presents an analysis of the impact in terms of direct and indirect benefits, as well as challenges. Tourism is considered a direct benefit, as tourism is one of the purposes of a short-stay visa. There was a rise in tourists from the visa-free countries after visa liberalisation across the EU Member States, although the numbers were modest in the context of overall tourism numbers to the EU. Residence permits for work or study reasons were considered an indirect benefit - as these are not purposes of stay for a short-stay Schengen visa, though a short stay could ultimately influence a longer stay for one of these reasons. The synthesised findings show that the number of residence permits issued to nationals of the visa-free countries more than doubled since 2008, and most of these were issued for employment reasons. Therefore, the report suggests that visa liberalisation could be a facilitator to labour market access. However, a similar link was not found for student migration or for entrepreneurship (EMN, 2019).

The synthesis report also highlights a number of challenges, a significant one being the rise in asylum applications in certain EU Member States, which occurred in some instances directly after visa liberalisation. The synthesis report shows that the impact was not consistent across EU Member States, with only some Member States experiencing significant increases. The study also examined irregular the basis of reciprocity, establishing rapid and effective procedures for the identification and safe and orderly return of persons who do not, or no longer, fulfil the conditions for entry to, presence in, or residence in the territories of the third country or one of the EU Member States, and facilitating the transit of such persons in a spirit of cooperation (EMN, 2018b). 
migration and overstay but, while some increases were noted, it did not establish a firm link between visa liberalisation and these phenomena. In the case of illegal employment, smuggling and human trafficking, the study did not establish a direct link between visa liberalisation and increases in these areas (EMN, 2019).

Ireland does not extend visa waivers to nationals of any of the countries covered by the study for direct travel to Ireland. In addition, nationals of some of the countries are required to have a transit visa to pass through Irish ports.

Four of the countries covered by the study - Bosnia and Herzegovina, Montenegro, Serbia and Ukraine - are included in the Irish Short Stay Visa Waiver Programme. This programme, which was introduced in 2011, allows for onward travel to Ireland from the UK to holders of UK short-stay visas, for the remainder of their UK leave to remain, or 90 days, whichever is shorter. It is a requirement of the programme to have cleared UK immigration prior to travel to Ireland. A total of 17 countries are included under it. ${ }^{5}$

It is not possible to attribute a direct impact of Schengen visa liberalisation to Ireland. However, Ireland shares some EU trends when it comes to increases in asylum applications. The data collected for this study show that, in the case of Georgia, the introduction of Schengen visa liberalisation has coincided with increased asylum flows towards Ireland. When applications under the EU relocation scheme are excluded, Georgia was the top country of origin for protection applications in Ireland during 2017 (302), an increase of over 300 per cent from 2016 (75). Most of the 2017 applications (288) were lodged between May and December of that year. The trend continued in 2018, with 173 protection applications from Georgian nationals lodged in the first four months of 2018, compared with only 14 in the same period in $2017 .{ }^{6}$ In total, 450 Georgian nationals made protection applications in $2018 .^{7}$

When relocation cases are excluded, Albania was the second highest country of origin for protection applicants in Ireland in 2017 and 2016, and third highest in 2014 and 2015. Albanian nationals made the highest number of protection applications (459) in 2018. ${ }^{8}$ However, as Table 4.2 shows, the large increases in protection applications from Albanian nationals started in 2014, four years after

A transit visa is used to allow nationals from certain countries to pass through an Irish airport/seaport to travel to another state; for example, on a connecting flight. See INIS, 'Transit visas', http://www.inis.gov.ie/en/INIS/Pages/Transit\%20Visas.

Correspondence with Policy Division, INIS, August 2018

International Protection Office, Statistics December 2018, www.ipo.gov.ie.

International Protection Office, Statistics December 2018, www.ipo.gov.ie. 
the introduction of Schengen visa liberalisation for Albania in 2010. It is therefore difficult to suggest a link to visa liberalisation in this case.

In June 2017, Ireland introduced transit visa requirements for Georgia and Ukraine. According to the Irish Naturalisation and Immigration Service (INIS), in the case of Georgia, 'this was a response to a very noticeable rise in Georgian nationals seeking to disembark in Ireland while in transit, and Ukraine was included as a preventative measure'. ${ }^{9}$

Ireland introduced the International Protection Act 2015 (Safe Countries of Origin) Order 2018 in April 2018. Under this Order, Georgia was designated as a safe country of origin. According to INIS, Schengen visa liberalisation was a deciding factor. ${ }^{10}$

Albania, Bosnia and Herzegovina, RNM, ${ }^{11}$ Montenegro and Serbia were also included on the safe country of origin list. However, according to INIS, Schengen visa liberalisation was not a deciding factor regarding these countries. The high volume of protection applicants was a deciding factor in the inclusion of Albania. ${ }^{12}$

In June 2018, some arrests were announced in the UK in relation to the alleged facilitation of irregular migration of Georgian nationals to the UK via Ireland. The arrests were the result of a joint investigation, commenced in June 2017, between Immigration Enforcement in the UK; the Garda National Immigration Bureau (GNIB) in Ireland, the Police Service of Northern Ireland and other law enforcement partners (Immigration Enforcement, June 2018).

The data available do not indicate an impact of Schengen visa waivers, for the countries covered by the study, on economic migration and tourism in Ireland. The Irish Short Stay Visa Waiver Programme was introduced to promote tourism and is considered to have been successful, particularly in relation to Chinese tourists in the country (Department of Justice and Equality, 2012). Disaggregated tourism statistics on the number of nights spent in hotels or other accommodation establishments (bed nights) from the countries covered by the study were not available due to survey sample size and statistical confidentiality. ${ }^{13}$ 
Introduction

\subsection{PURPOSE AND SCOPE OF THE STUDY}

This report is based on material from the Irish contribution to the European Migration Network (EMN) study, Impact of visa liberalisation on countries of destination, which was carried out by the EMN National Contact Points during 2018. The EMN synthesis report was published in March 2019 (EMN, 2019). ${ }^{14}$

The EMN study sought to assess the effects of visa-free movement on cross-border mobility to the Schengen Area of the EU and Norway, and the impact of enhanced cross-border mobility on the countries of destination, following successful visa liberalisation dialogues between the EU and certain third countries in the Western Balkans and from the Eastern Partnership (EaP). The visa liberalisation agreements allow for a Schengen visa waiver - a short-stay visa waiver for holders of biometric passports from the respective third country. The countries covered by the scope of the study, and the dates of their visa liberalisation agreements with the EU, are listed below.

- Republic of North Macedonia (RNM) (19 December 2009) ${ }^{15}$

- Montenegro (19 December 2009)

- Serbia (19 December 2009)

- Albania (15 December 2010)

- Bosnia and Herzegovina (15 December 2010)

- Moldova (28 April 2014)

- Georgia (28 March 2017)

- Ukraine (11 June 2017).

The time period for this study is 2007-2017, with a focus on the two years preceding and/or following the visa liberalisation agreement entering into force for each country. However, as data were largely unavailable for 2007 , the data presented in the synthesis report mostly run from 2008 to 2017. Data in the synthesis report exclude Ireland and the UK, as neither country participates in the EU's common visa policy. Where relevant, data from Ireland and the UK are presented separately in the synthesis report in order to compare trends. In this national report, additional data are reported for 2018 and 2019 in relation to asylum applications in Ireland, in order to illustrate continuing trends.

See http://emn.ie/cat_publication_detail.jsp?clog=1\&itemID=3190\&t=6.

On 14 February 2019, the country formerly known as the Former Yugoslav Republic of Macedonia (FYROM) changed its name to the Republic of North Macedonia (RNM) - see www.un.org. 
The EMN study was based on a hypothesis that 'visa liberalisation yields effects on cross-border mobility' (EMN, 2019). A challenge in this regard was defining the effect of visa liberalisation on cross-border mobility: whether direct causal impacts could be attributed to visa liberalisation; or correlative effects, specifically, noticeable trends with a temporal link to the visa liberalisation agreement date. The synthesis report notes that: 'the report does not establish a causal link between visa liberalisation and its findings, but rather indicates a correlation between the two and any explanations are descriptive' (EMN, 2019).

These effects could include both challenges and positive impacts on destination Member States. Positive impacts considered within the study include: increases in tourism, investment, trade and flows of workers and students following the visa liberalisation agreements. Challenges considered include: increases in asylum applications by nationals of the third countries concerned; increases in irregular migration; and possible misuse of the visa-free regimes, including facilitation of irregular migration, trafficking and illegal employment.

\subsection{REPORT OUTLINE}

An important context of this national report is the fact that Ireland is not part of the Schengen Area, and does not participate in the EU's common visa policy. Furthermore, nationals of all the countries covered by the study are required to have a visa for direct travel to Ireland. ${ }^{16}$ Therefore, enhanced visa-free travel to the Schengen Area does not have a direct impact on Ireland. This report seeks to provide a parallel overview of trends in migration to Ireland of nationals of the countries concerned, in circumstances where there is no visa waiver for these nationals to travel to Ireland. It looks at whether or not any link can be adduced between visa-free travel in the Schengen Area and migratory trends towards Ireland from these countries. It employs the statistical indicators used for the EMN study, where data were available.

Chapter 2 sets out the legal and policy framework in relation to the visa liberalisation agreements concluded between the EU and the eight countries covered by the study. It also sets out the legal framework for the Irish visa system.

Chapter 3 reviews direct and indirect impacts of visa liberalisation on countries of destination as defined by the synthesis report. It looks at impacts on tourism, economic and student migration and on other EU Member States and sets out the migratory trends to Ireland from the visa-free countries, regarding legal migration. 
It also summarises the situation regarding return, including voluntary return, from other EU Member States and Ireland to the visa-free countries.

Chapter 4 looks at challenges experienced by countries of destination as a result of visa-free travel of people from those countries included in the scope of the study. These include increases in asylum applications and challenges in relation to irregular migration, overstay and facilitation of irregular migration. It sets out the circumstances where similar trends are observed in Ireland.

\subsection{METHODOLOGY}

This report is based on information gathered according to commonly agreed EMN study specifications for the EU-wide study, Impact of visa liberalisation on countries of destination (EMN, 2019). As with all EMN studies, a similar report was produced by the other EMN National Contact Points. Desk research was undertaken at the outset, including a review of existing policy-based literature, government department or ministerial press statements, parliamentary debates and media sources. Eurostat data were in general used, supplemented in specific instances by data provided by the Irish Naturalisation and Immigration Service (INIS). Written consultations, based on questionnaires, were undertaken with a number of areas within INIS, including the policy section, the International Protection Office (IPO), repatriation, visas, and border management.

The EMN synthesis study used quantitative data from statistical indicators related to border control, asylum, legal migration, irregular migration and return in order to draw links between visa liberalisation, possible consequent increases in crossborder mobility, and impacts in countries of destination. ${ }^{17}$

Ireland did not contribute to most of these statistical indicators, either because: a) they related to the Schengen Area and were not relevant to Ireland's legal regime, an example here being crossings of the Schengen external border; $b$ ) no data were available because no nationals of the third countries concerned came to Ireland for the specific purpose covered by the statistical indicator; or c) no data were available because either the sample size was too small or Ireland does not collate data in this manner.

The statistical indicators used included: border crossings; asylum applications and decisions; return decisions and removals; irregular migration and overstay; illegal employment; identity document fraud; smuggling; trafficking; tourism; and residence permits issued for remunerated, entrepreneurial and education reasons. 
For this reason, this overview will focus on those indicators for which Ireland provided meaningful data: protection applications; refusals of leave to land; return decisions and removals; and first-residence permits issued by reason.

For the purpose of this study, any reference to a 'visa-free country' means a country within the scope of this study that has a visa liberalisation agreement in place with the European Union, and which provides for a Schengen visa waiver for its nationals, who are holders of biometric passports. 


\section{Legal and political context}

\subsection{LEGAL CONTEXT}

\subsubsection{European Union}

The EU's common visa policy is a cornerstone of the way in which it controls the entry of third-country nationals (TCN) into the Schengen Area. As envisaged by the Visa Code (Council Regulation 810/2009), ${ }^{18}$ the development of common legislative rules was considered one of the fundamental components of 'further development of the common visa policy as part of a multi-layer system aimed at facilitating legitimate travel and tackling illegal immigration. ${ }^{\prime 19}$

The Schengen Area includes 22 EU Member States and the four (non-EU) European Free Trade Association (EFTA) countries - Iceland, Liechtenstein, Norway and Switzerland. Ireland, like the United Kingdom (UK), is not part of the Schengen Area, or the EU's common visa policy; Ireland is therefore not bound by most of the border-related provisions of the Schengen acquis. ${ }^{20}$ Four other EU Member States - Bulgaria, Croatia, Cyprus and Romania - are not yet part of the Schengen Area; they do not fully apply the Schengen acquis and do not take part in the common visa policy (European Commission, 2018a).

Council Regulation 539/2001 (as amended) sets out the lists of countries whose nationals are required (Annex I) or not required (Annex II) to hold a Schengen visa. ${ }^{21}$ Council Regulation 810/2009 - the Visa Code - sets out the procedures and conditions for issuing Schengen visas. The Visa Code provides that certain thirdcountry nationals may be exempt from its provisions, in line with the list in place under Annex II of Council Regulation 539/2001. The Schengen Borders Code (Regulation 2016/399) controls entry to the Schengen Area. ${ }^{22}$ Article 6 sets out the requirements to cross the external Schengen border, including the possession of a valid visa (unless a waiver applies) and proof of purpose of stay and means of subsistence.

\footnotetext{
18 Regulation (EC) No 810/2009 of the European Parliament and of the Council of 13 July 2009 establishing a community code on visas (the Visa Code). Ibid., Recital 3.

Schengen acquis - body of EU legislation including the Schengen agreements and associated legislation. Council Regulation (EC) No 539/2001 of 15 March 2001 listing the third countries whose nationals must be in possession of visas when crossing the external borders and those whose nationals are exempt from that requirement.

22 Regulation (EU) 2016/399 of the European Parliament and of the Council of 9 March 2016 on a union code on the rules governing the movement of persons across borders (the Schengen Borders Code).
} 
A Schengen visa is a short-stay visa allowing the holder entry into the Schengen Area for 90 days within a 180-day period, and can also be issued for airport transit. ${ }^{23,24}$ The purpose of the Schengen visa can relate to tourism, family or business. ${ }^{25}$ Long-stay visas (for example in relation to employment) remain within the competence of the individual Member State (EMN, 2019).

The visa waivers enjoyed by nationals of the countries covered by the study were agreed following bilateral visa liberalisation dialogues between the EU and each individual country. The visa exemptions for the countries covered by this study only apply to holders of biometric passports (EMN, 2019).

\subsubsection{Ireland}

Ireland is not part of the Schengen Area and does not participate in the EU's common visa policy. ${ }^{26} \mathrm{~A}$ factor in this regard is preservation of the Common Travel Area between Ireland and the UK. The Minister for Justice and Equality has noted that, 'We have only been able to maintain the Common Travel Area because we have remained outside the Schengen area' (Department of Justice and Equality, 2019). It has also been noted that 'there is a particularly close operational relationship with the UK authorities in managing the security of the Common Travel Area between Ireland and the UK' (Department of Justice and Equality, 2017).

Nationals of the countries covered by this study are, in general, required to have a visa to travel to Ireland. In addition, nationals of some of those countries are required to have a transit visa, to pass through an Irish airport or seaport to travel to another state, for example, on a connecting flight. ${ }^{27}$

Ireland does not extend visa waivers to nationals of any of the countries covered by the study for direct travel to Ireland. The Irish Short Stay Visa Waiver Programme, which was introduced in 2011, allows for onward travel to Ireland from the UK to holders of UK short-stay visas, for the remainder of their UK leave to remain or 90 days, whichever is shorter. It is a requirement of the programme to have cleared UK immigration prior to travel to Ireland. A total of 17 countries are included under the Programme. ${ }^{28}$ This includes four of the countries included

Article 77 (2) of the Treaty on the Functioning of the European Union provides the legal basis for adoption of common rules on short stay visas and conditions under which third country nationals can travel within the Union for a short period.

25 See Annex II to the Visa Code (Regulation 810/2009) - 'Non-exhaustive list of supporting documents' for categories of purpose of visit.

26 Council Decision 2002/192/EC sets out those aspects of the Schengen acquis in which Ireland has requested to participate.

27 See INIS, 'Transit visas', http://www.inis.gov.ie/en/INIS/Pages/Transit\%20Visas.

28 The 17 countries included in the programme are: Bahrain, Belarus, Bosnia and Herzegovina, China, India, Kazakhstan, Kuwait, Montenegro, Oman, Qatar, Russia, Saudi Arabia, Serbia, Thailand, Turkey, Ukraine, and 
in this European Migration Network (EMN) study - Bosnia and Herzegovina, Montenegro, Serbia and Ukraine.

Table 2.1 summarises the position regarding visas for each country covered by the remit of this study.

TABLE 2.1 VISA REQUIREMENTS IN IRELAND FOR NATIONALS OF COUNTRIES COVERED BY THE STUDY

\begin{tabular}{|l|l|l|l|}
\hline Country & $\begin{array}{l}\text { Visa required (short } \\
\text { or long stay) }\end{array}$ & Transit visa required & Short Stay Visa Waiver Programme \\
\hline Albania & Yes & Yes & No \\
$\begin{array}{l}\text { Bosnia and } \\
\text { Herzegovina }\end{array}$ & Yes & No & Yes, added to eligible countries in 2012. \\
\hline Georgia & Yes & Yes, introduced in June & No \\
\hline Moldova & Yes & Yes & No \\
\hline Montenegro & Yes & No, removed in 2012. & $\begin{array}{l}\text { Yes, included since programme began in } \\
2011 .\end{array}$ \\
\hline RNM & Yes & No & No \\
\hline Serbia & Yes & No, removed in 2012. & $\begin{array}{l}\text { Yes, included since programme began in } \\
2011 .\end{array}$ \\
\hline Ukraine & Yes & Yes, introduced in June & $\begin{array}{l}\text { Yes, included since programme began in } \\
2011 .\end{array}$ \\
\hline
\end{tabular}

The following points regarding the Irish visa system are relevant.

- In Ireland, a short-stay ' $C$ ' visa allows a person to travel to Irelandfor stays of up to up to 90 days. ${ }^{29}$

- If a third country national (TCN) family member of an EU/EEA/Swiss national has a 'holding a residence card of a family member of an EU citizen', within the meaning of Article 10 of Directive 2004/38/EC, then they do not require a visa. ${ }^{30}$

- A holder of a 'Convention travel document', issued in accordance with Article 28 of the Geneva Convention, may not be subject to a visa requirement for short stays of up to 90 days in Ireland. In order for the holder of such a travel document to be exempt from an Irish visa requirement for short stays, the travel document must be issued by a European state that is a contracting party to the European Agreement on the Abolition of Visas for Refugees. ${ }^{31}$

Uzbekistan. United Arab Emirates (UAE) was included up to January 2018. The visa requirement for nationals of UAE to travel to Ireland was lifted in January 2018.

29 See INIS, 'Your Irish visa', available at http://www.inis.gov.ie/en/INIS/Pages/visa-how-to-read-visa.

30 INIS, 'Residence card of a family member of an EU citizen', available at http://www.inis.gov.ie/en/INIS/Pages/visaeu-family-residence-card.

31 This applies to Convention travel documents issued by the following countries: Belgium, the Czech Republic, Denmark, Finland, Germany, Hungary, Iceland, Italy, Liechtenstein, Luxembourg, Malta, the Netherlands, Norway, 
- In Ireland, a visa is a form of pre-entry clearance to travel to a point of entry to the State only (Quinn, 2011). The border guard has the power to grant or refuse permission to land under the Immigration Act $2004 .{ }^{32}$ If TCNs stay in Ireland for longer than 90 days, they are required to register with the immigration authorities for a residence permission. This applies to all TCNs, not just those who require a visa. ${ }^{33}$

\section{Irish Short Stay Visa Waiver Programme}

The Irish Short Stay Visa Waiver Programme was introduced in July 2011 as part of the Government's strategy, under the Jobs Initiative scheme, to promote tourism to Ireland (INIS, 2016a)..$^{34}$ The programme applies to people from 17 countries including Bosnia and Herzegovina, Montenegro, Serbia and Ukraine. It targeted countries based on recommendations from the tourism industry of countries with potential for growth in tourism to Ireland, as well as the success rate in applications for visas (Department of Justice and Equality, 2012). ${ }^{35}$

The programme allows for travel to Ireland for a maximum period of 90 days for nationals of eligible countries who hold an UK short-stay visa and who have landed in the UK and cleared UK immigration. It does not apply to direct travel to Ireland. This programme is not a reciprocal visa programme; a UK visa is required to travel to the UK, including Northern Ireland.

Nationals of those countries covered by the programme who have entered the UK on a ' $C$ ' general visa, and who have been granted leave to remain in the UK for up to 180 days, may travel to Ireland within the time remaining on the current UK 'leave to remain', without the requirement to obtain an Irish visa. ${ }^{36}$ They may be granted permission to remain in Ireland for a period of up to a maximum of 90 days or for the time left on their UK leave to remain, whichever is shorter.

Holders of diplomatic and special passports from the countries under the programme are also eligible, and certain conditions apply in certain circumstances.

Poland, Portugal, Romania, the Slovak Republic, Spain, Sweden and Switzerland. INIS, 'Visas policy and guidance: Convention travel documents', available at http://www.inis.gov.ie/en/INIS/Pages/Convention+travel+documents. Immigration Act 2004, s 4.

Immigration Act 2004, s 4. See also: INIS, 'How the Irish immigration system works', available at http://www.inis.gov.ie/en/INIS/Pages/about-registration-system.

The Jobs Initiative scheme was announced by the Irish government in May 2011, with the aim of assisting in employment generation, providing opportunities for those who have lost their jobs, and thus generating confidence in the economy. The Short Stay Visa Waiver Programme was one initiative within this scheme designed to encourage tourism. See 'Jobs Initiative booklet - 10 May 2011', available at www.merrionstreet.ie. The 17 countries included in the programme are Bahrain, Belarus, Bosnia and Herzegovina, China, India, Kazakhstan, Kuwait, Montenegro, Oman, Qatar, Russia, Saudi Arabia, Serbia, Thailand, Turkey, Ukraine and Uzbekistan. Montenegro, Serbia and Ukraine were on the initial list of countries included in the programme in 2011, while Bosnia and Herzegovina was added to the programme in March 2012.

A standard visitor visa may be granted for reasons including tourism and business and permission to stay may be granted for up to 180 days. See www.gov.uk-standard-visitor-visa. 
It is a requirement of the programme that those who avail of it have landed and gained lawful entry to the UK, prior to travel to Ireland. Transit passengers through the UK to Ireland, who do not pass through immigration, will still require an Irish visa.

Nationals of countries covered by the programme who are long-term residents in the UK or the Schengen Area require a visa to travel to Ireland, but visa fees are waived under the programme (INIS, 2016a).

\subsection{POLITICAL CONTEXT}

\subsubsection{EU level}

\section{Visa liberalisation dialogues}

The visa waivers enjoyed by nationals of the countries covered by this study were agreed following bilateral visa liberalisation dialogues between the EU and the countries concerned. These were staged processes began with visa facilitation agreements and readmission agreements, before progressing in accordance with visa liberalisation road maps for the Western Balkan countries and visa liberalisation action plans for the Eastern Partnership (EaP) countries. ${ }^{37}$

The roadmaps and action plans were marked by periodic progress reports undertaken by the European Commission to assess whether the required benchmarks were being achieved. These benchmarks included: document security including biometrics; border management; migration and asylum; public order and security; and external relations and fundamental rights. ${ }^{38}$

Following approval of visa liberalisation, the countries with visa liberalisation agreements are required to continue to comply with the visa liberalisation benchmarks.

The visa suspension mechanism was first introduced in $2013^{39}$ and revised in $2017 .^{40}$ It allows the European Commission or a Member State to temporarily suspend a visa exemption for a third country in the event of a substantial increase when crossing the external borders and those whose nationals are exempt from that requirement. 
in irregular migration, or a substantial increase in the risk to public policy or internal security of the Member States, which may arise from visa-free travel. The revised mechanism also requires the European Commission to monitor and report on the continued fulfilment of the visa liberalisation benchmarks by countries who have concluded a visa liberalisation agreement with the EU (European Commission, 2018d; Council of the European Union, 2017). In this regard, the European Commission has published two reports on the visa suspension mechanism (European Commission, 2017; European Commission, 2018b; European Commission 2018c), the first of which falls within the temporal scope of this study.

According to the European Commission (2018b):

The visa-free regime brings important benefits for citizens and reinforces social, cultural and economic ties between the EU and its partners. At the same time, the visa-free regime also brings responsibilities to sustain the progress achieved under visa liberalisation dialogues and ensure a well-managed migration and security environment, including through a visa policy that is aligned with the EU acquis.

The First report under the visa suspension mechanism (European Commission, 2017) found that the visa liberalisation benchmarks continued to be fulfilled for all of the countries covered by this study. However, the report also contained recommendations to ensure continued compliance, in particular regarding irregular migration (including unfounded asylum applications); combating organised crime; and anti-corruption and anti-money laundering measures. The first report noted that the readmission agreements with the visa-free countries were working well and that return rates were high (European Commission, 2017). Similarly, the second report (European Commission, 2018b) found that the benchmarks continued to be met, but again recommended urgent action in relation to curbing irregular migration, and fighting organised crime and corruption (European Commission, 2018c). Several of the benchmarks used by the European Commission for their monitoring exercise were used by the EMN as statistical indicators and as a basis for questions in the study specifications (EMN, 2019). ${ }^{41}$

\subsubsection{Ireland}

There has been little discussion of Schengen visa liberalisation in Ireland as it is not directly applicable to Ireland. However, there has been some discussion regarding the conditions and benchmarks required for countries to achieve visa liberalisation, and some calls for parallel visa waivers in the Irish system. 
In May 2015, the Minister for Foreign Affairs of Georgia, Tamar Beruchashvili, published an opinion piece in The Irish Times in advance of the Eastern Partnership Summit in Riga, Latvia on 21-22 May 2015. Regarding the plans for Schengen visa liberalisation he said:

[r]emoving visa requirements for Georgian citizens will mean more tourism, cultural and student exchanges, and civil society partnerships. This will help develop Georgia and anchor the next generations firmly within the European family of nations. Most importantly, it will provide a clear demonstration to the people of Georgia, including in the occupied territories of Abkhazia and South Ossetia, and to those of the other Eastern Partnership countries, that the EU upholds a merit-based approach and delivers on its promises. For Georgians, visa liberalisation will provide a long-awaited tangible reward for reforms and encourage renewed efforts.

(Beruchashvili, 2015)

There has been some discussion in parliamentary debates about the introduction of parallel visa exemptions to the Schengen waivers in the Irish visa system. In 2018, a parliamentary question asked if the Schengen visa waiver for Ukrainian nationals could be extended to Ireland. In the response to the parliamentary question, the Minister for Justice and Equality explained that Ireland is not bound by the Schengen acquis and that there were currently no plans to lift the visa requirement for Ukrainian nationals. The Minister said:

[i]n considering this, a range of factors need to be considered including general compliance with the visa regime, the close alignment of our visa system with that in the United Kingdom in order to protect the integrity of the Common Travel Area, and more generally broader immigration policy. ${ }^{42,43}$

On 29 March 2018, a delegation from the Parliament of Georgia Foreign Relations Committee visited the Irish Parliament's Committee on Foreign Relations, Trade and Defence. In their address, the Georgian delegation referred to visa-free travel for their nationals in the Schengen Area, saying:

Georgian citizens continue to benefit from the visa-free travel regime. This is the most visible and tangible benefit for the entire population of Georgia and an additional incentive for the Government of Georgia to continue the pace of reforms. 
The Georgian Government is fully committed to sustained reforms in all these visa liberalisation action plan-related areas, with particular attention given to the prevention of possible abuse of the asylum system in the Schengen countries.

The delegation called for various improvements to Ireland-Georgia relations, including: deeper economic and trade cooperation between Ireland and Georgia; opening of an Irish embassy in Tbilisi; and the easing of visa restrictions for Georgian citizens travelling to Ireland. In particular, they requested a diplomatic visa waiver as the starting point of this process. Greater cooperation in the field of education was also mentioned by the Georgian delegation. Some Irish committee members supported the idea of a diplomatic visa waiver and the chairman undertook that the Committee would raise this issue with the Minister for Justice and Equality (Joint Oireachtas Committee on Foreign Affairs and Trade, and Defence, 2018). 


\section{Impacts of visa liberalisation}

\subsection{TOURISM}

\subsubsection{EU}

The European Migration Network (EMN) synthesis report measures the impact of visa liberalisation on tourism to the EU. This was an expected impact, as one of the purposes of visa liberalisation was 'to foster short-term stays to the EU such as tourist visits' (EMN, 2019). The indicator that was used for this was the number of visitors staying in hotels and other accommodation in EU Member States and Norway. The report acknowledges that this indicator does not capture the full picture, as many visitors may stay with friends and family (EMN, 2019).

The synthesis report reports that the total number of visitors staying in hotels in the EU who were from those Western Balkan and Eastern Partnership (EaP) countries covered by the study more than doubled between $2009(935,000)$, when visa liberalisation for the first group of Western Balkan countries was introduced, and $2017(2,316,000) \cdot{ }^{44}$ Of the Western Balkan countries, most of the visitors were from Bosnia and Herzegovina and Serbia. The vast majority of the visitors from the three EaP countries were from Ukraine, across the full 2007-2017 period. Visa liberalisation was not introduced for Ukrainian nationals until June 2017. The synthesis report points out that the share of visitors from these countries did not exceed 0.6 per cent of total third-country national and EU visitors. The increase should also be viewed in the context of the overall increase of tourists to the EU during the period (EMN, 2019).

\subsubsection{Ireland}

The total number of overseas trips and bed-nights spent in Ireland by non-residents increased from 6,907,000 in 2009 to 9,932,000 in 2017 - an increase of 43 per cent. ${ }^{45}$ However, it is not possible to say whether Ireland experienced a growth in tourism from nationals of countries covered by the study, as data on the number of overseas trips to Ireland by non-residents and the number of bed-nights spent in Ireland by non-residents are broken down by region of residence, not by

\footnotetext{
44 This was based on national data supplied by: Austria (on Ukraine data only); Belgium; the Czech Republic (for data on Serbia, Montenegro and Ukraine, as of 2012); Estonia (only on Albania and Ukraine); Greece (only regarding Albania); Spain (data only as of 2013); Finland; Croatia (on Albania only, as of 2011, no data on Moldova and Georgia); Hungary; Ireland (only regarding Ukraine); Italy; Lithuania (data only as of 2012); Luxembourg (data on Montenegro and Georgia only, as of 2010); Latvia (only regarding Georgia and Ukraine); the Netherlands (on Ukraine only); Poland; Sweden; Slovenia (data only as of 2015); the Slovak Republic (only regarding Montenegro, Serbia and Ukraine); and Norway (data only as of 2017) (EMN, 2019). 
nationality. A further breakdown of data was not available 'for reasons due to survey sample size and statistical confidentiality'. ${ }^{46}$

The Irish Short-stay Visa Waiver Programme was introduced as part of efforts to promote tourism (INIS, 2016a). The programme, which applies to persons from 17 countries ${ }^{47}$ including Bosnia and Herzegovina, Montenegro, Serbia and Ukraine, targeted countries based on recommendations from the tourism industry of countries with potential for growth in tourism to Ireland as well as the success rate in applications for visas (Department of Justice and Equality, 2012). Schengen visa liberalisation had already been in place for Bosnia and Herzegovina, Montenegro and Serbia for two years prior to their respective addition to the programme. Visafree travel in the Schengen Area had not been introduced for nationals of Ukraine at the time of Ukraine's addition to the programme in 2011.

The programme has been viewed by Government as contributing to a growth in tourism from the countries involved (Department of Justice and Equality, 2013a). Furthermore, it was 'deemed a success by the tourism sector and it has been extended twice as a result'. ${ }^{48}$ Its most recent extension in 2016 was highlighted as providing 'a significant boost to efforts to attract more visitors to Ireland from these countries' (Department of Justice and Equality, 2016). In extending the programme in 2012, the Department of Justice noted that the number of visits by persons from the countries covered by the programme was 38 per cent higher than in 2010 (Department of Justice and Equality 2013b). In particular, tourism from China has been highlighted as an outcome (Department of Justice and Equality, 2012).

Due to a lack of disaggregated data, it is not possible to determine the extent to which the growth in tourism under the programme can be attributed to visits from third-country nationals of those countries included in the programme who are also entitled to visa-free travel in the Schengen Area.

\subsection{LEGAL MIGRATION}

The synthesis report discusses whether or not visa liberalisation had an indirect impact on economic and student migration from the visa-free countries to the EU. While Schengen visas are short stay only, the synthesis report posits that:

\footnotetext{
$46 \quad$ Correspondence with Tourism Section, Central Statistics Office, August 2018.

47 The 17 countries included in the programme are: Bahrain, Belarus, Bosnia and Herzegovina, China, India, Kazakhstan, Kuwait, Montenegro, Oman, Qatar, Russia, Saudi Arabia, Serbia, Thailand, Turkey, Ukraine, and Uzbekistan. Montenegro, Serbia and Ukraine were on the initial list of countries included in the programme in 2011, while Bosnia and Herzegovina was added to the programme in March 2012. 
a visa-free regime that fosters mobility, improves regional cooperation between individual countries and creates more open societies, may exert some effect on the choice of people to establish themselves in the EU for economic or other reasons (EMN, 2019).

\subsubsection{Economic migration}

\section{EU}

Eurostat data collected for the synthesis report show that residence permits granted for the first time (first permits) to nationals of the visa-free countries rose from 358,000 in 2008 to 830,000 in 2017. (Ireland and the UK were not included in this dataset due to not taking part in the Common EU visa policy.) First permits issued for remunerated reasons comprise the largest proportion of all firstresidence permits issued each year to nationals of the visa-free countries; for example, in 2017, 652,000 permits out of a total of 830,000 first permits were for remunerated reasons (EMN, 2019). First permits for remunerated reasons are set out in Table 3.1.

TABLE 3.1 FIRST-RESIDENCE PERMITS ISSUED IN THE EU AND NORWAY TO NATIONALS OF COUNTRIES WITHIN THE SCOPE OF THE STUDY (EXCLUDING IRELAND AND UK), 20082017

\begin{tabular}{|c|c|c|c|c|c|c|c|c|c|c|}
\hline $\begin{array}{l}\text { Permits } \\
\text { issued to: }\end{array}$ & 2008 & $2009 *$ & 2010* & 2011 & 2012 & 2013 & $2014^{*}$ & 2015 & 2016 & $2017^{*}$ \\
\hline $\begin{array}{l}\text { Nationals of } \\
\text { visa-free } \\
\text { countries for } \\
\text { remunerated } \\
\text { reasons }\end{array}$ & 189,000 & 121,000 & 214,000 & 121,000 & 136,000 & 182,000 & 236,000 & 403,000 & 526,000 & 642,000 \\
\hline $\begin{array}{l}\text { All third- } \\
\text { country } \\
\text { nationals for } \\
\text { remunerated } \\
\text { reasons }\end{array}$ & 648,000 & 534,000 & 673,000 & 420,000 & 379,000 & 429,000 & 459,000 & 591,000 & 737,000 & 903,000 \\
\hline $\begin{array}{l}\text { Notes: } \\
\text { Source: }\end{array}$ & $\begin{array}{l}\text { a waiver a६ } \\
\text { tenegro a } \\
\text { ch } 2017 \text { fo } \\
, 2019 .\end{array}$ & $\begin{array}{l}\text { Serbent dat } \\
\text { Serbia; } 15 \\
\text { eorgia; an }\end{array}$ & $\begin{array}{l}\text { re } 19 \mathrm{De} \\
\text { cember } \\
\text { June } 20\end{array}$ & $\begin{array}{l}\text { ber } 2009 \mathrm{fc} \\
0 \text { for Albar } \\
\text { or Ukraine }\end{array}$ & $\begin{array}{l}\text { he Republ } \\
\text { Bosnia al }\end{array}$ & $\begin{array}{l}\text { of North } ~ \\
\text { Herzegov }\end{array}$ & $\begin{array}{l}\text { edonia (RI } \\
\text {; } 28 \text { April }\end{array}$ & $\begin{array}{l}\text { formerly } \\
4 \text { for Molc }\end{array}$ & $\begin{array}{l}\text { OM), } \\
\text { a; } 28\end{array}$ & \\
\hline
\end{tabular}

The synthesis report notes that visa liberalisation, of itself, does not give rise to any right to labour market access in the Member States and that, in general, thirdcountry nationals would need to apply for a residence permit for economic reasons from outside the territory of the Member State. However, in eight Member States 
and in Norway, third-country nationals can apply for a residence permit while legally staying in the Member State. ${ }^{49}$ The synthesis report thus concludes:

\begin{abstract}
.... $[v]$ isa liberalisation could facilitate a third-country national to undertake one or more short trips to explore employment opportunities in a Member State of his/her choice and in some cases, make an application for residence on the grounds of employment from the territory of the Member State.
\end{abstract}

(EMN, 2019)

\title{
Ireland
}

Ireland does not participate in Schengen visa liberalisation; it is therefore not possible to quantify a direct impact on Ireland from the countries benefiting from the Schengen visa waiver in terms of economic migration. In addition, the data show that numbers of residence permits issued in Ireland to nationals benefiting from the visa liberalisation agreements for the Schengen Area are low.

Table 3.2 shows that residence permits were issued to nationals of the visa-free countries coming to Ireland for remuneration reasons in the period 2008-2017. However, all the permits issued to nationals of the visa-free countries for remuneration reasons represented only around two per cent of the overall number of permits issued for remuneration reasons in Ireland each year since 2010 (the figure was slightly higher, at four to five per cent in 2008 and 2009). The numbers of residence permits remained relatively constant both before and after Schengen visa liberalisation. 
TABLE 3.2 FIRST-RESIDENCE PERMITS ISSUED IN IRELAND FOR REMUNERATED ACTIVITIES TO NATIONALS OF COUNTRIES WITHIN THE SCOPE OF THE STUDY, 2008-2017

\begin{tabular}{|c|c|c|c|c|c|c|c|c|c|c|}
\hline Country nationalities & 2008 & 2009* & $2010 *$ & 2011 & 2012 & 2013 & 2014* & 2015 & 2016 & $2017^{*}$ \\
\hline Albania & 2 & 5 & 5 & 3 & 5 & 3 & 2 & 4 & 8 & 7 \\
\hline $\begin{array}{l}\text { Bosnia and } \\
\text { Herzegovina }\end{array}$ & 3 & 3 & 3 & 3 & 3 & 1 & 7 & 1 & 8 & 8 \\
\hline Georgia & 2 & 4 & 1 & 6 & 3 & 3 & 5 & 5 & 2 & 1 \\
\hline Moldova & 19 & 52 & 22 & 11 & 3 & 4 & 8 & 6 & 6 & 5 \\
\hline Montenegro & 0 & 0 & 0 & 0 & 0 & 0 & 0 & 0 & 0 & 3 \\
\hline RNM & 8 & 2 & 0 & 2 & 2 & 3 & 1 & 3 & 10 & 3 \\
\hline Serbia & 6 & 13 & 7 & 13 & 17 & 9 & 12 & 21 & 37 & 30 \\
\hline Ukraine & 194 & 177 & 36 & 36 & 49 & 48 & 60 & 94 & 116 & 128 \\
\hline $\begin{array}{l}\text { Total (issued by } \\
\text { Ireland) }\end{array}$ & 234 & 256 & 74 & 74 & 82 & 71 & 95 & 134 & 187 & 185 \\
\hline \multicolumn{11}{|l|}{$\begin{array}{l}\text { Permits issued to all } \\
\text { third country }\end{array}$} \\
\hline $\begin{array}{l}\text { nationals for } \\
\text { remunerated } \\
\text { activities reasons }\end{array}$ & 5,808 & 4,827 & 3,208 & 3,425 & 3,720 & 4,018 & 5,139 & 6,073 & 7,842 & 9,398 \\
\hline $\begin{array}{ll}\text { Notes: } & \text { * Visa waiver a } \\
& \text { Montenegro a } \\
& \text { March } 2017 \mathrm{fo} \\
\text { Source: } & \text { Eurostat migr }\end{array}$ & $\begin{array}{l}\text { eement } \\
\text { Serbia; } \\
\text { Georgia; } \\
\text { sfirst. Da }\end{array}$ & $\begin{array}{l}\text { s are } 19 \\
\text { Decemb } \\
11 \text { June } \\
\text { extracted }\end{array}$ & $\begin{array}{l}\text { cember } 2 \\
2010 \text { for } \\
17 \text { for Uk } \\
27 \text { May }\end{array}$ & $\begin{array}{l}9 \text { for th } \\
\text { oania, B } \\
\text { ne. } \\
19 .\end{array}$ & $\begin{array}{l}\text { public of } \\
\text { ia and } \mathrm{He}\end{array}$ & $\begin{array}{l}\text { th Mace } \\
\text { govina; }\end{array}$ & $\begin{array}{l}\text { nia (RNM } \\
\text { April } 201\end{array}$ & $\begin{array}{l}\text { ormerly } \\
\text { for Mol }\end{array}$ & $\begin{array}{l}\text { OM), } \\
\text { a; } 28\end{array}$ & \\
\hline
\end{tabular}

In Ireland, residence permits are issued for stays of longer than 90 days. ${ }^{50}$ Therefore, similar to other EU Member States, anyone issued with a permit for remuneration reasons would generally not have entered Ireland on a short-stay visa. However, under the Atypical Working Scheme, permission may be granted for periods both less and greater than 90 days. Those who apply for this scheme may enter Ireland on the basis of a ' $C$ ' short-stay visa, if they intend to stay in Ireland for a period of less than 90 days. Those who are granted a contract under the scheme for longer than 90 days are required to enter Ireland on a ' $D$ ' long-stay visa.

People who avail of the Atypical Working Scheme usually do so in the context of a contract for services or the medical sector (Sheridan, 2017). About 60 per cent of applications under this scheme are made by nationals of south-east Asian countries, while 20 per cent are from North America and a further 20 per cent from a range of other countries. A very limited number of nationals of the countries

50 Third-country nationals who intend to stay in Ireland for longer than 90 days are required to apply for permission to stay in Ireland. Once a residence permission is granted, third-country nationals must then register their permission with the INIS. On registering, an Irish Residence Permit is issued, which indicates the conditions of the holder's immigration permission. 
with visa liberalisation agreements for the Schengen Area have availed of the scheme since it began in 2013. ${ }^{51}$

\subsubsection{Entrepreneurs}

The synthesis report reports some increase in the number of residence permits issued for entrepreneurial reasons (including self-employment) to nationals of the visa-free countries. However, the overall numbers remained too low to reveal any discernible trend (EMN, 2019). In Ireland, there were no approved applications from nationals of the visa-free countries under the Start-up Entrepreneur Programme (STEP) or the Immigrant Investor Programme (IIP). ${ }^{52}$

\subsection{STUDENT MIGRATION}

\subsubsection{EU}

At EU level, a gradual increase was noted in the numbers of students coming to the EU from the visa-free countries over the period 2008-2017, as shown in Table 3.3. However, the synthesis report concludes that a clear link between visa liberalisation and this rise cannot be established, citing other relevant factors, such as national policies and cultural links (EMN, 2019). According to the synthesis report, visa-free nationals from the countries covered by the study accounted for, on average, about a five per cent share of all third-country nationals (first permits) migrating for education reasons to the EU and Norway (EMN, 2019). 
TABLE 3.3 FIRST-RESIDENCE PERMITS ISSUED FOR EDUCATION REASONS IN THE EU AND NORWAY TO NATIONALS OF COUNTRIES WITHIN THE SCOPE OF THE STUDY (EXCLUDING IRELAND AND THE UK), 2008-2017

\begin{tabular}{|c|c|c|c|c|c|c|c|c|c|c|}
\hline $\begin{array}{l}\text { Permits issued } \\
\text { to: }\end{array}$ & 2008 & $2009 *$ & 2010* & 2011 & 2012 & 2013 & $2014 *$ & 2015 & 2016 & $2017^{*}$ \\
\hline $\begin{array}{l}\text { Nationals of } \\
\text { visa-free } \\
\text { countries for } \\
\text { education } \\
\text { reasons }\end{array}$ & 17,700 & 13,600 & 14,800 & 13,400 & 16,800 & 24,200 & 30,400 & 39,800 & 34,400 & 33,700 \\
\hline $\begin{array}{l}\text { All third- } \\
\text { country } \\
\text { nationals for } \\
\text { education } \\
\text { reasons }\end{array}$ & 223,200 & 226,700 & 228,900 & 234,700 & 243,200 & 263,500 & 280,100 & 278,800 & 310,700 & 328,900 \\
\hline $\begin{array}{l}\text { Note: } \\
\text { Sources: }\end{array}$ & $\begin{array}{l}\text { sa waiver a } \\
\text { ntenegro a } \\
\text { rch } 2017 \text { fo } \\
\text { N, 2019; Eu }\end{array}$ & $\begin{array}{l}\text { eement dat } \\
\text { Serbia; } 15 \\
\text { Georgia; anc } \\
\text { stat migr_r }\end{array}$ & $\begin{array}{l}\text { are } 19 \text { Dec } \\
\text { ecember } 2 \\
11 \text { June } 201 \\
\text { first. Data e }\end{array}$ & $\begin{array}{l}\text { aber } 2009 \mathrm{fc} \\
0 \text { for Alban } \\
\text { for Ukraine. } \\
\text { racted on } 2\end{array}$ & $\begin{array}{l}\text { he Republic } \\
\text { Bosnia anc } \\
\text { une } 2019 \text {. }\end{array}$ & $\begin{array}{l}\text { North M } \\
\text { erzegovir }\end{array}$ & $\begin{array}{l}\text { onia (RN } \\
8 \text { April } 2\end{array}$ & $\begin{array}{l}\text { ormerly F } \\
\text { for Mold }\end{array}$ & $\begin{array}{l}\text { M), } \\
; 28\end{array}$ & \\
\hline
\end{tabular}

\subsubsection{Ireland}

In Ireland, education is the main reason for which first-residence permits are issued each year. For example, in 2017, first-residence permits issued for education reasons represented 57 per cent of all first-residence permits issued to thirdcountry nationals. As shown in Table 3.4, the total first-residence permits issued to nationals of visa-free countries for education reasons represent less than one per cent of total permits issued for education reasons in Ireland each year, remaining stable before and after Schengen visa liberalisation for each country. 
TABLE 3.4 FIRST-RESIDENCE PERMITS ISSUED IN IRELAND FOR EDUCATION REASONS TO NATIONALS OF COUNTRIES WITHIN THE SCOPE OF THE STUDY, 2008-2017

\begin{tabular}{|c|c|c|c|c|c|c|c|c|c|c|}
\hline $\begin{array}{c}\text { Country } \\
\text { nationalities }\end{array}$ & 2008 & $2009 *$ & $2010 *$ & 2011 & 2012 & 2013 & 2014 & 2015 & 2016 & $2017^{*}$ \\
\hline Albania & 5 & 5 & 8 & 10 & 7 & 11 & 9 & 9 & 4 & 9 \\
\hline $\begin{array}{l}\text { Bosnia and } \\
\text { Herzegovina }\end{array}$ & 6 & 4 & 19 & 20 & 17 & 16 & 11 & 12 & 7 & 12 \\
\hline Georgia & 5 & 11 & 5 & 8 & 5 & 5 & 6 & 13 & 7 & 16 \\
\hline Moldova & 30 & 28 & 32 & 24 & 20 & 7 & 11 & 5 & 1 & 5 \\
\hline Montenegro & 0 & 0 & 0 & 5 & 1 & 1 & 0 & 1 & 0 & 0 \\
\hline RNM & 6 & 1 & 3 & 3 & 1 & 3 & 4 & 2 & 2 & 2 \\
\hline Serbia & 1 & 4 & 9 & 18 & 6 & 7 & 10 & 7 & 7 & 7 \\
\hline Ukraine & 37 & 40 & 44 & 51 & 40 & 47 & 56 & 56 & 35 & 57 \\
\hline Total & 90 & 93 & 120 & 139 & 97 & 97 & 107 & 105 & 63 & 108 \\
\hline $\begin{array}{l}\text { Permits issued } \\
\text { to all third- } \\
\text { country } \\
\text { nationals for } \\
\text { education } \\
\text { reasons }\end{array}$ & 12,538 & 12,263 & 13,653 & 15,131 & 16,828 & 21,394 & 23,730 & 22,075 & 21,421 & 27,588 \\
\hline $\begin{array}{ll}\text { otes: } & \text { *Visa wai } \\
& \text { Monteneg } \\
& \text { March 20 } \\
\text { urce: } & \text { Eurostat n }\end{array}$ & $\begin{array}{l}\text { sreement } \\
\text { dd Serbia; } \\
\text { Georgia; } \\
\text { resfirst. D }\end{array}$ & $\begin{array}{l}\text { lates are } 19 \\
15 \text { Decemb } \\
\text { and } 11 \text { June } \\
\text { ta extracte }\end{array}$ & $\begin{array}{l}\text { ecember } \\
2010 \text { fo } \\
017 \text { for } \mathrm{L} \\
\text { on } 27 \mathrm{Ma}\end{array}$ & $\begin{array}{l}009 \text { for the } \\
\text { Albania, Bo } \\
\text { raine. } \\
2019 .\end{array}$ & $\begin{array}{l}\text { oublic o } \\
\text { a and } \mathrm{H}\end{array}$ & $\begin{array}{l}\text { rth Mac } \\
\text { egovina }\end{array}$ & $\begin{array}{l}\text { nia (RNN } \\
\text { April } 20\end{array}$ & $\begin{array}{l}\text { ormerly } \\
\text { for Mol }\end{array}$ & $\begin{array}{l}\text { OM), } \\
\text { a; } 28\end{array}$ & \\
\hline
\end{tabular}

\subsection{RETURN AND READMISSION}

\subsubsection{EU}

The synthesis report states that cooperation between the visa-free countries and EU countries on return and readmission was effective. This ties in with the European Commission's positive assessment regarding cooperation on readmission in the First report on the visa suspension mechanism (European Commission, 2017). The synthesis report also notes that the numbers of return decisions across the entire period of 2008-2017 were relatively stable. Regarding (assisted) voluntary return, the synthesis report notes fluctuations in uptake over the same period, not necessarily linked to visa liberalisation dates. However, in Belgium, uptake of voluntary return for nationals of Serbia and North Macedonia increased significantly (more than 280 per cent and more than 600 per cent respectively) in the years following visa liberalisation. The number of Albanian nationals taking up voluntary return in Belgium increased 20 times between 2009 and 2011. Similar trends regarding increased voluntary return uptake by Albanian nationals were noted in France (2016-2017) and Germany (2014-2016) (EMN, 2019). 


\subsubsection{Ireland}

Ireland's framework regarding return differs from other EU Member States in a number of ways. Firstly, Ireland is not bound by the EU Return Directive (2008/115/EC), which is a measure that builds on aspects of the Schengen acquis, in which Ireland does not participate. Secondly, while Ireland opted into EU readmission agreements with Albania, Bosnia and Herzegovina, RNM, Montenegro, Moldova, Serbia and Georgia in early 2014, bilateral protocols are not yet in place and these agreements are not operational for Ireland..$^{53}$ Thirdly, as Ireland does not participate in the EU's common visa policy and the readmission agreements are not operational for Ireland, the benchmark of successful implementation of the readmission agreements with the visa waiver countries is not relevant to Ireland. It is therefore extremely difficult to draw correlations between Ireland's experience and that of other EU Member States regarding returns to the visa waiver countries.

Table 3.5 shows that the proportion of return decisions issued to nationals from the visa-free countries in Ireland ranged from 7.7 per cent to 18.3 per cent over the period 2008-2017.

The Irish Naturalisation and Immigration Service (INIS) commented that, as of September 2018, there was no discernible impact on return decisions from the large increase in Georgian protection applicants since May 2017. ${ }^{54}$ 
TABLE 3.5 RETURN DECISIONS ISSUED IN IRELAND TO NATIONALS FROM COUNTRIES WITHIN THE SCOPE OF THE STUDY, 2008-2017

\begin{tabular}{|c|c|c|c|c|c|c|c|c|c|c|}
\hline Visa-free countries & 2008 & 2009* & 2010* & 2011 & 2012 & 2013 & $2014^{*}$ & 2015 & 2016 & $2017^{*}$ \\
\hline Albania & 5 & 15 & 20 & 35 & 25 & 5 & 15 & 25 & 70 & 20 \\
\hline Bosnia and Herzegovina & 0 & 0 & 0 & 0 & 0 & 0 & 0 & 0 & 0 & 0 \\
\hline Georgia & 15 & 45 & 135 & 70 & 120 & 45 & 20 & 20 & 40 & 30 \\
\hline Moldova & 135 & 140 & 105 & 85 & 95 & 155 & 30 & 20 & 30 & 15 \\
\hline Montenegro & 0 & 0 & 0 & 0 & 0 & 0 & 0 & 0 & 0 & 0 \\
\hline RNM & 5 & 0 & 0 & 0 & 0 & 0 & 0 & 0 & 0 & 0 \\
\hline Serbia & 15 & 0 & 5 & 0 & 0 & 5 & 0 & 0 & 0 & 0 \\
\hline Ukraine & 15 & 15 & 10 & 15 & 45 & 20 & 10 & 20 & 15 & 25 \\
\hline Total & 190 & 215 & 275 & 205 & 285 & 230 & 75 & 85 & 155 & 90 \\
\hline $\begin{array}{l}\text { Return decisions issued to all } \\
\text { third-country nationals }\end{array}$ & 1,285 & 1,615 & 1,495 & 1,805 & 2,065 & 2,145 & 970 & 875 & 1,355 & 1,105 \\
\hline
\end{tabular}

\footnotetext{
Notes: Data are rounded to nearest five.

* Visa waiver agreement dates are 19 December 2009 for the Republic of North Macedonia (RNM, formerly FYROM),

Montenegro and Serbia; 15 December 2010 for Albania, Bosnia and Herzegovina; 28 April 2014 for Moldova; 28

March 2017 for Georgia; and 11 June 2017 for Ukraine.

Source: Eurostat: migr_eiord. Data extracted on 27 May 2019.
}

Data that were available from 2012 to 2017, shown in Table 3.6, show that the proportion of deportation orders effected in respect of third-country nationals from the visa-free countries ranged from 2.7 per cent to 14.5 per cent of all effected deportation orders. 
TABLE 3.6 FORCED RETURNS FROM IRELAND OF NATIONALS OF COUNTRIES WITHIN THE SCOPE OF THE STUDY, 2012-2017

\begin{tabular}{|c|c|c|c|c|c|c|}
\hline & 2012 & 2013 & $2014^{*}$ & 2015 & 2016 & $2017 *$ \\
\hline Forced returns of those from visa-free countries & 44 & 27 & 6 & 7 & 28 & 15 \\
\hline Forced returns of all third-country nationals & 302 & 209 & 114 & 251 & 428 & 140 \\
\hline $\begin{array}{ll}\text { Notes: } & \text { *Visa waiver agreement dates are } 19 \text { December } 2009 \\
& \text { Montenegro and Serbia; } 15 \text { December } 2010 \text { for Alba } \\
& \text { March } 2017 \text { for Georgia; and } 11 \text { June } 2017 \text { for Ukrain } \\
\text { Source: } & \text { Correspondence with INIS, } 2018 .\end{array}$ & $\begin{array}{l}\text { the Rep } \\
\text {, Bosnia }\end{array}$ & $\begin{array}{l}\text { of Nort } \\
\text { Herzeg }\end{array}$ & $\begin{array}{l}\text { cedonia } \\
\text { a; } 28 \mathrm{Ap}\end{array}$ & $\begin{array}{l}M, \text { form } \\
014 \text { for }\end{array}$ & $\begin{array}{l}\text { YROM), } \\
\text { ova; } 28\end{array}$ & \\
\hline
\end{tabular}

Table 3.7 shows data available for voluntary returns (including assisted) from Ireland by nationals of visa-free countries from 2012 to 2017. The proportion of voluntary returns to the visa-free countries ranged from eight to 20.7 per cent of the total voluntary returns. The largest number of voluntary returns in real number terms was in respect of Moldovan nationals in 2012 and 2013 (61 and 41 respectively)..$^{55}$

TABLE 3.7 VOLUNTARY RETURNS (INCLUDING ASSISTED) FROM IRELAND BY NATIONALS OF COUNTRIES WITHIN THE SCOPE OF THE STUDY, 2012-2017

\begin{tabular}{|l|c|c|c|c|c|c|}
\hline & 2012 & 2013 & $2014^{*}$ & 2015 & $2016^{*}$ & $2017^{*}$ \\
\hline $\begin{array}{l}\text { Voluntary returns (all types) by } \\
\text { nationals of visa-free countries }\end{array}$ & 92 & 56 & 27 & 12 & 13 & 17 \\
$\begin{array}{l}\text { Voluntary returns (all types) by } \\
\text { all third-country nationals }\end{array}$ & 444 & 424 & 231 & 117 & 161 & 176 \\
\hline
\end{tabular}

Notes: * Visa waiver agreement dates are 19 December 2009 for the Republic of North Macedonia (RNM, formerly FYROM) Montenegro and Serbia; 15 December 2010 for Albania, Bosnia and Herzegovina; 28 April 2014 for Moldova; 28 March 2017 for Georgia; and 11 June 2017 for Ukraine.

Source: $\quad$ Correspondence with INIS, 2018.

Uptake of voluntary returns by nationals of the countries covered by this study is generally low. ${ }^{56}$ For example, none of those countries features in the top five countries for which the International Organization for Migration (IOM) Ireland provided assisted return in 2016 (Sheridan, 2017). IOM places a large emphasis on information dissemination (Coakley, 2015). In 2013, IOM Ireland reported that it had made efforts to consolidate its information and outreach among migrants, including through placing information on assisted voluntary return and reintegration (AVRR) directly with Georgian communities resident in Ireland (Coakley, 2015). There was low uptake of voluntary return by Georgian nationals (ten or less) in 2013 and future years. ${ }^{57}$ However, Ukraine and Georgia were among the top four countries for which IOM Ireland provided assisted return in 2017 (Sheridan, 2018). Ukraine was the third highest nationality of total voluntary 
24 Trends in migration to Ireland of nationals of countries with visa liberalisation agreements

returns (all types) in 2017, and the second highest nationality to take up assisted voluntary return. Georgia was the joint third highest nationality to take up assisted voluntary return in 2017 (EMN, 2018a). However, as Table 3.7 shows, numbers in real terms are small. 


\section{CHAPTER 4}

\section{Challenges associated with visa liberalisation}

The European Commission found in its first and second reports on the visa suspension mechanism that all the visa-free countries continued to fulfil the visa liberalisation requirements (European Commission, 2017; European Commission, 2018b). At the same time, the Commission made recommendations for additional efforts to tackle irregular migration and increased (including unfounded) asylum applications from some of the concerned countries. For example, the Commission's Second report under the visa suspension mechanism recommended that Georgia, '[s]trengthen the operational cooperation with concerned countries to achieve a swift decrease in the number of unfounded asylum applications by Georgian nationals in the Schengen+ area' (European Commission, 2018b). All the visa-free countries were required to set up targeted information campaigns clarifying the rights and entitlements arising from visa-free travel to the EU in both the Commission's 2017 and 2018 reports (EMN, 2019). The Commission's reports also recommended that the visa-free countries needed to make further efforts to combat organised crime. According to the Commission,

\section{[o]rganised crime groups from these countries continue to be active in trafficking of illicit firearms and various illicit commodities (in particular drugs and tobacco), property crime, money laundering, trafficking in human beings, smuggling of migrants and cybercrime (European Commission, 2018b).}

It is important to note that while these are migratory challenges reported in relation to the third countries covered by the study, they are not necessarily attributable to Schengen visa liberalisation. The synthesis report states, 'the available data could not reliably isolate the effects of visa liberalisation from other factors and the report must be understood in this context' (EMN, 2019).

\subsection{ASYLUM APPLICATIONS}

\subsubsection{EU level}

Twelve Member States, including Ireland, reported a rise in the number of asylum applications from visa-free nationals (EMN, 2019). ${ }^{58}$ As shown in Table 4.1, total asylum applications received in EU countries (excluding Ireland and the UK) from visa-free nationals rose from 24,000 in 2008 to 157,000 in 2015, reducing again to 
65,000 by 2017 . Those received by Ireland and the UK combined fluctuated from 400 in 2008 to 2,800 in 2017 (the highest point). ${ }^{59}$

TABLE 4.1 ASYLUM APPLICATIONS RECEIVED IN THE EU AND NORWAY FROM NATIONALS OF COUNTRIES WITHIN THE SCOPE OF THE STUDY, 2008-2017

\begin{tabular}{|c|c|c|c|c|c|c|c|c|c|c|}
\hline & 2008 & $2009 *$ & $2010^{*}$ & 2011 & 2012 & 2013 & $2014 *$ & 2015 & 2016 & $2017 *$ \\
\hline $\begin{array}{l}\text { EU (excl. Ireland } \\
\text { and UK) }\end{array}$ & 24,000 & 22,000 & 38,000 & 34,000 & 55,000 & 61,000 & 92,000 & 157,000 & 83,000 & 65,000 \\
\hline Ireland and UK & 400 & 700 & 500 & 700 & 1,300 & 1,900 & 2,600 & 2,700 & 2,400 & 2,800 \\
\hline Source: & $\begin{array}{l}\text { Visa waiver } \\
\text { Montenegro } \\
\text { March } 2017 \\
\text { MN, } 2019 .\end{array}$ & $\begin{array}{l}\text { ement da } \\
\text { Serbia; } 1 \\
\text { eorgia; ar }\end{array}$ & $\begin{array}{l}\text { are } 19 \mathrm{De} \\
\text { ecember } \\
11 \text { June } 20\end{array}$ & $\begin{array}{l}\text { aber } 2009 \\
0 \text { for Alba } \\
\text { for Ukraine }\end{array}$ & $\begin{array}{l}\text { Repul } \\
\text { Bosnia }\end{array}$ & $\begin{array}{l}\text { North } N \\
\text { erzegovi }\end{array}$ & $\begin{array}{l}\text { Lonia (RN } \\
8 \text { April } 2\end{array}$ & $\begin{array}{l}\text { rmerly FYF } \\
\text { for Moldo }\end{array}$ & & \\
\hline
\end{tabular}

The synthesis report states that the increase in asylum applications was not evenly distributed across EU Member States and Norway; some Member States had large increases, while others had close to none. Several Member States registered zero or no asylum applications from visa-free countries after visa liberalisation. ${ }^{60}$ The report also notes that the spike in applications in 2015 must be seen in the context of the migration crisis $-760,000$ of the irregular border crossings into the Schengen Area in 2015 were recorded on the Western Balkans route. Similarly, in some Member States, an increase in applications could largely relate to one specific visafree nationality. For example, in the UK, Albanian nationals accounted for most of the increase in applications from the Western Balkans. According to the synthesis report: '[i]n Germany and France, most applications came from Albania, Serbia, North Macedonia, and later Georgia and Ukraine' (EMN, 2019).

The report states that the 'exact impact of visa liberalisation on the number of asylum applications from visa-free countries cannot be measured' and posits that other factors such as 'internal political unrest (e.g. Ukraine), unemployment, poverty and discrimination played a role'. However, it also suggests that 'visa liberalisation at least made it easier for nationals of these countries to arrive in the EU and lodge a claim for asylum' (EMN, 2019).

The synthesis report sets out the proportion of positive and negative decisions in the EU and Norway as a whole, including Ireland, on asylum applications for each of the visa-free countries over the period 2008-2017. Negative decisions regarding

\footnotetext{
$59 \quad$ Eurostat data, which are rounded, are used here.

60 Bulgaria and the Czech Republic (only in the case of Montenegro and Albania); Estonia, Croatia, Montenegro, Portugal, Romania, the Slovak Republic, Slovenia and the UK (in the case of Montenegro nationals). Ireland had no, or close to no, applications from Bosnia and Herzegovina, Montenegro, RNM or Serbia.
} 
each visa-free country came in at above 94 per cent, with the exception of Ukraine, which was 78 per cent (EMN, 2019).

\subsubsection{Ireland}

Table 4.2 sets out asylum applications from nationals of the visa-free countries in Ireland for the period 2008-2017. National data are used where asylum applications are above 10, and rounded Eurostat data, denoted by two asterisks, is used in all other cases. 
TABLE 4.2 ASYLUM/INTERNATIONAL PROTECTION APPLICATIONS RECEIVED IN IRELAND FROM NATIONALS OF COUNTRIES WITHIN THE SCOPE OF THE STUDY, 2008-2017

\begin{tabular}{|c|c|c|c|c|c|c|c|c|c|c|}
\hline Visa-free countries & 2008 & $2009 *$ & $2010 *$ & 2011 & 2012 & 2013 & $2014^{*}$ & 2015 & 2016 & $2017^{*}$ \\
\hline Albania & 51 & 47 & 13 & 34 & 46 & 48 & 99 & 214 & 222 & 282 \\
\hline $\begin{array}{l}\text { Bosnia and } \\
\text { Herzegovina }\end{array}$ & $0 * *$ & $0 * *$ & $0 * *$ & $0 * *$ & $0 * *$ & $0 * *$ & $0 * *$ & $0 * *$ & $0 * *$ & $0 * *$ \\
\hline Georgia & 181 & 88 & 53 & 15 & 19 & 15 & 18 & 39 & 75 & 302 \\
\hline Moldova & 141 & 88 & 56 & 27 & 17 & $5^{* *}$ & $5^{* *}$ & $5^{* *}$ & $5^{* *}$ & $5^{* *}$ \\
\hline Montenegro & $0 * *$ & $0 * *$ & $0 * *$ & $0 * *$ & $0 * *$ & $0 * *$ & $0 * *$ & $0 * *$ & $0 * *$ & $0 * *$ \\
\hline RNM & $0 * *$ & $0 * *$ & $0 * *$ & $0 * *$ & $0 * *$ & $0 * *$ & $0 * *$ & $0 * *$ & $0 * *$ & $0 * *$ \\
\hline Serbia & $40^{* *}$ & $0 * *$ & $5 * *$ & $0 * *$ & $0 * *$ & $0 * *$ & $0 * *$ & $0 * *$ & $0 * *$ & $0 * *$ \\
\hline Ukraine & 20 & 17 & $5 * *$ & $10^{* *}$ & 14 & $10 * *$ & 49 & 47 & 20 & 15 \\
\hline $\begin{array}{l}\text { Total from visa-free } \\
\text { countries }^{61}\end{array}$ & 399 & 244 & 133 & 86 & 99 & 76 & 169 & 309 & 321 & 602 \\
\hline $\begin{array}{l}\text { Asylum/internationa } \\
\text { I protection } \\
\text { applications } \\
\text { received in Ireland } \\
\text { from all third- } \\
\text { country nationals }\end{array}$ & 3,864 & 2,691 & 1,943 & 1,292 & 959 & 946 & 1,448 & 3,276 & 2,244 & 2,926 \\
\hline $\begin{array}{ll}\text { Notes: } & \text { * Visa } \\
& \text { Mont } \\
& \text { Marc } \\
& \text { extra } \\
\text { Source: } & \text { IPO a }\end{array}$ & $\begin{array}{l}\text { iver agree } \\
\text { gro and } S \\
017 \text { for } \mathrm{Ge} \\
\text { on } 27 \mathrm{M} \\
\text { Eurostat } \mathrm{n}\end{array}$ & $\begin{array}{l}\text { int dates a } \\
\text { ia; } 15 \text { Dec } \\
\text { jia; and } 11 \\
2019 . \\
\text { asyappct }\end{array}$ & $\begin{array}{l}19 \text { Decemb } \\
\text { nber } 2010 \\
\text { une } 2017 \mathrm{f}\end{array}$ & $\begin{array}{l}2009 \text { for } t \\
\text { Albania, } \\
\text { Ukraine. }\end{array}$ & $\begin{array}{l}\text { Republic o } \\
\text { snia and } \\
\text { ndicates } 4\end{array}$ & $\begin{array}{l}\text { orth Mace } \\
\text { egovina; } \\
\text { of rounde }\end{array}$ & $\begin{array}{l}\text { ia (RNM, f } \\
\text { April } 2014 \\
\text { urostat da }\end{array}$ & $\begin{array}{l}\text { merly FYR } \\
\text { r Moldov } \\
\text { Eurostat }\end{array}$ & & \\
\hline
\end{tabular}

\section{Albania}

The data in Table 4.2 show that there have been increasing flows of protection applicants from Albania to Ireland. Numbers of protection applications increased significantly between 2014 (99) and 2017 (282). Albania was the second highest country of origin among protection applications in 2017, after Georgia, at 11.7 per cent of total applications (when cases under the EU relocation programme are excluded). ${ }^{62}$ Albania was also the second highest nationality for protection applications in 2016 (222), after Pakistan. Albanian nationals represented the third highest nationality among applications in 2014 and 2015. ${ }^{63}$ Albanian nationals made the highest number of protection applications (459) in 2018. ${ }^{64}$ However, the large increases in protection applications from Albania began in 2014, four years

\footnotetext{
61 As Eurostat data are rounded, individual values will not add up to the totals. Totals are from national data records.

62 The 2017 figure includes protection applicants that were relocated from Greece under the EU relocation programme. At 545 applications, Syria was the top nationality for protection applicants in 2017. Applicants from Syria were mostly relocation cases (Sheridan, 2018).

63 Correspondence with Policy Division, INIS, August 2018

64 Statistics December 2018, International Protection Office, available at www.ipo.gov.ie.
} 
after visa-free travel to the Schengen Area came into force for Albania (in 2010). The numbers of applications in $\mathbf{2 0 1 0}$ were low and there were small increases from 2012 to 2013. Based on the data, it would not seem possible to suggest an immediate temporal link between the introduction of Schengen visa liberalisation for Albania in 2010 and the rise in protection applications in later years.

\section{Georgia}

There has been a large increase in protection applications from nationals of Georgia since the introduction of Schengen visa liberalisation for Georgia, on 28 March 2017. When cases under the EU relocation programme are excluded, Georgia was the country of origin with the highest number of protection applicants in 2017. When relocation cases are excluded, Georgia accounted for 12.6 per cent of protection applications for 2017 (2,402). As shown in Table 4.2, there was an over 300 per cent increase in the number of applicants in 2017 when compared to 2016. ${ }^{65}$ The Irish Naturalisation and Immigration Service (INIS) has noted that most of the applications (288) were lodged in the period May to December 2017. ${ }^{66}$ This trend continued in 2018, with 173 protection applications from Georgian nationals lodged in the first four months of 2018 compared with only 14 during the same period in $2017 .{ }^{67} \mathrm{~A}$ total of 450 Georgian nationals made protection applications in 2018, the second highest nationality after Albania. ${ }^{68}$

As of 31 March 2019, protection applications from Albanian nationals in Ireland have increased 147 per cent ( 85 versus 210 applications) when compared to the first quarter of 2018, while applications from Georgian nationals decreased (142 versus 118 applications) by 17 per cent in the same quarter. ${ }^{69}$

The synthesis report notes that Ireland and the UK experienced similar trends in relation to other EU Member States in terms of asylum applications, despite not applying visa liberalisation. The report suggests that this could be partly explained by 'the fact that visa-free travel to the EU might also have an impact on facilitating travel to Ireland and the United Kingdom' (EMN, 2019).

\subsubsection{Policy measures taken by Member States in response to increase in asylum applications}

The synthesis report sets out the policy actions taken by Member States to respond to increases in asylum applications in the context of the migration crisis of 20142016. However, some of these policy responses were also relevant to increased asylum applications from the Western Balkan and Eastern Partnership (EaP) 
countries. One of these policy measures comprised adding visa liberalisation countries to national lists of safe countries of origin, although visa liberalisation was not necessarily the motivator in their inclusion. Fifteen Member States, including Ireland, added Albania, Bosnia and Herzegovina, the Republic of North Macedonia (RNM), Montenegro and Serbia to safe country lists, or applied the safe country concept to them. ${ }^{70} \mathrm{~A}$ lesser number of Member States included Georgia, ${ }^{71}$ Moldova $^{72}$ and Ukraine ${ }^{73}$ on their safe country of origin lists (EMN, 2019).

On 16 April 2018, the Minister for Justice and Equality in Ireland included North Macedonia, Montenegro, Serbia and Bosnia and Herzegovina as designated safe countries of origin, under the International Protection Act 2015 (Safe Countries of Origin) Order 2018. ${ }^{7475}$ According to INIS, Schengen visa liberalisation was not a factor in the inclusion of these countries on the list. These countries were included in Ireland's safe country of origin list to more closely align the list to those operating in other EU Member States.

The high number of protection applications received from nationals of Albania was a factor in the inclusion of Albania in the safe countries of origin list from the same date. Georgia was also included in the list pursuant to the same Order, due to a large increase in the number of international protection applications lodged by nationals of Georgia from 2017. According to INIS, Schengen visa liberalisation was a factor in the decision to include Georgia on the list. ${ }^{76}$

Ireland also introduced a transit visa requirement in respect of Georgian and Ukrainian nationals in June 2017, via the Immigration Act 2004 (Visas) Order 2017. ${ }^{77}$ According to INIS,

[T]ransit visa requirements are generally put in place to assist in identifying travellers that may pose a risk of disembarking in transit and either claiming asylum or attempting to remain in the country illegally or travelling onward to the UK. In the case of Georgia, there was a very noticeable rise in Georgian nationals seeking to disembark in Ireland while in transit following the introduction of visa free Netherlands, Slovenia and the UK. Finland and Norway do not have national lists of safe countries of origin but apply the safe country concept in the examination of asylum applications. Austria, Belgium, Bulgaria, France, Ireland and the Netherlands (not safe in specific regions). Norway applied the safe country concept.

France and the UK. Norway applied the safe country concept.

Austria, Bulgaria, Luxembourg, the Netherlands (not safe in specific regions) and the UK.

S.I. No. 121 of 2018.

Republic of North Macedonia is called Former Yugoslav Republic of Macedonia in the statutory instrument Correspondence with Policy Division, INIS, August 2018.

S.I. No. 264 of 2017. 
Schengen status for Georgian nationals. The transit visa requirement was put in place to lower the risk of such actions.

Ukraine was included at the time as a preventative measure. ${ }^{78}$

\subsection{IRREGULAR MIGRATION}

Member States reported a number of irregular migration challenges for the synthesis report. The most often reported challenge was irregular stay (19 Member States), followed by refusal of entry at external borders (15 Member States) (EMN, 2019). Again, it is important to note that, while these are migratory challenges experienced by Member States in relation to these third countries, they may not be necessarily attributable to visa liberalisation.

Eurostat data on refusals of entry at the Irish external border, shown in Table 4.3, show an increase in refusals of entry at the external border for Albanian and Georgian nationals. The figures show that refusals of entry for Albanian nationals began to climb after 2010, the date of entry into force of Schengen visa liberalisation for Albania. There was an increase in refusals of permission to land for Georgian nationals, from 70 in 2016 to 270 in 2017. It should be noted that while these upward trends coincided with the introduction of visa-free travel in the Schengen Area for these nationalities, they were still subject to an Irish entry visa. 
TABLE 4.3 NATIONALS OF COUNTRIES WITHIN THE SCOPE OF THE STUDY REFUSED ENTRY AT THE IRISH EXTERNAL BORDERS, 2008-2017

\begin{tabular}{|c|c|c|c|c|c|c|c|c|c|c|}
\hline & 2008 & 2009* & 2010* & 2011 & 2012 & 2013 & $2014^{*}$ & 2015 & 2016 & $2017 *$ \\
\hline Albania & 40 & 25 & 25 & 130 & 115 & 100 & 255 & 345 & 430 & 405 \\
\hline $\begin{array}{l}\text { Bosnia and } \\
\text { Herzegovina }\end{array}$ & 5 & 5 & 0 & 0 & 0 & 0 & 0 & 0 & 0 & 0 \\
\hline Georgia & 15 & 15 & 10 & 5 & 10 & 10 & 5 & 15 & 70 & 270 \\
\hline Moldova & 65 & 25 & 30 & 15 & 10 & 15 & 15 & 20 & 15 & 20 \\
\hline Montenegro & 0 & 0 & 0 & 0 & 0 & 0 & 0 & 0 & 0 & 0 \\
\hline RNM & 0 & 0 & 0 & 0 & 0 & 0 & 0 & 0 & 0 & 0 \\
\hline Serbia & 15 & 10 & 0 & 0 & 0 & 0 & 0 & 5 & 0 & 5 \\
\hline Ukraine & 40 & 35 & 40 & 50 & 30 & 30 & 75 & 75 & 30 & 25 \\
\hline Total & 180 & 115 & 105 & 205 & 165 & 155 & 350 & 460 & 545 & 725 \\
\hline $\begin{array}{l}\text { Third-country } \\
\text { nationals } \\
\text { refused entry } \\
\text { at Irish } \\
\text { external } \\
\text { borders }\end{array}$ & 5,260 & 3,560 & 2,790 & 2,545 & 2,205 & 1,935 & 2,475 & 3,450 & 3,950 & 3,745 \\
\hline $\begin{array}{ll}\text { Notes: } & \text { * Visa wai } \\
& \text { Monteneg } \\
& \text { March 20 } \\
& \text { extracted } \\
\text { Source: } & \text { Eurostat: }\end{array}$ & $\begin{array}{l}\text { reement d } \\
\text { id Serbia; } \\
\text { Georgia; } \\
\text { May } 2019 \\
\text { eirfs. }\end{array}$ & $\begin{array}{l}\text { es are } 19 \mathrm{D} \\
\text { December } \\
\text { d } 11 \text { June }\end{array}$ & $\begin{array}{l}\text { ember } 200 \\
010 \text { for Al } \\
117 \text { for Ukr }\end{array}$ & $\begin{array}{l}\text { for the R } \\
\text { nia, Bos } \\
\text { ne. ** in }\end{array}$ & $\begin{array}{l}\text { blic of Nor } \\
\text { and Herze } \\
\text { tes use of }\end{array}$ & $\begin{array}{l}\text { Macedo } \\
\text { vina; } 28 \\
\text { bunded E }\end{array}$ & $\begin{array}{l}\text { RNM, for } \\
\text { I } 2014 \mathrm{ff} \\
\text { tat data }\end{array}$ & $\begin{array}{l}\text { ly FYROM) } \\
\text { loldova; } 28 \\
\text { rostat data }\end{array}$ & & \\
\hline
\end{tabular}

In 2017, Albanian nationals accounted for 10.8 per cent of total refusals of entry at the Irish border. In the same year, Georgia accounted for approximately seven per cent of the total refusals of entry.

Data published by INIS on people removed from the State, in its annual Immigration in Ireland: Annual review, include both deportations and people removed after refusal of entry, who are returned to the place they had travelled from (INIS, 2018, 2017 and 2016b). Albanian nationals accounted for 10.4 per cent of people removed from the State in 2017, which ranked it the highest nationality in this regard. Georgia ranked the third-highest nationality regarding people removed from the State in 2017; most of these removals relate to refusals of entry (INIS, 2018). ${ }^{79}$ Albania was the second highest country of origin for people removed in 2016, at 9.9 per cent of the total (INIS, 2017); in 2015, the figure was 9.2 per cent of the total (INIS, 2016b).

79 In 2017, the total of 3,968 people removed from the State included 3,746 refusals of entry, 140 deportations, and $82 \mathrm{EU}$ nationals removed on foot of EU removal orders (INIS, 2018). 


\subsection{FACILITATION OF IRREGULAR ENTRY}

The synthesis report does not draw any conclusive links between facilitation of irregular entry and smuggling and visa liberalisation. This is due to a lack of data and the fact that most actions taken to combat facilitation and smuggling are general in nature. A hypothesis of the effect of visa liberalisation on facilitation of irregular migration and smuggling was that 'overall it would reduce the demand for such services from nationals of the visa-free countries as most could lawfully enter the Schengen area'. However, the synthesis report does not confirm this effect (EMN, 2019).

Ireland did not contribute to the statistical indicators on identifying facilitators of irregular migration or on smuggled persons, as data were not available. However, Ireland reported on a joint investigation with the UK authorities into alleged facilitation of the unauthorised entry of Georgian nationals into the UK via Ireland (Immigration Enforcement, 2018). In June 2018, the UK Home Office (Immigration Enforcement Criminal and Financial Investigation) announced arrests resulting from this joint investigation. It was undertaken by the Joint Agency Taskforce, comprising the Irish Garda National Immigration Bureau (GNIB), UK Immigration Enforcement, the Police Service of Northern Ireland (PSNI), and other law enforcement partners, and its aim was to dismantle an organised crime group suspected to be involved in the facilitation of the unauthorised entry of nationals of Georgia into the UK through Ireland. Seven suspects were arrested and charged in the UK for assisting an unknown number of Georgian nationals to gain unauthorised entry to the UK. A number of people were charged with conspiracy to facilitate illegal immigration, assisting unlawful immigration or identity document offences. They were remanded to appear in court at a later stage (Immigration Enforcement, 2018).

The Irish police commented that the investigation was 'an example of the continued co-operation between the relevant agencies in our efforts to target all types of criminal activity, including illegal immigration in both jurisdictions' (Immigration Enforcement, 2018).

Media sources reported that the investigation was prompted by an upsurge in asylum applications from Georgian nationals in Ireland in 2017, which it was noted had occurred following Schengen visa liberalisation for Georgia in 2017 (Lally, 2018). 



\section{CHAPTER 5}

\section{Conclusions}

Ireland is outside the Schengen Area and not bound by the EU's common visa policy. It is therefore not possible to draw any conclusions about a direct impact of Schengen visa liberalisation on migration to Ireland.

Neither is it possible to draw parallels between one visa-free regime and another, as Ireland does not extend visa waivers to nationalities who benefit from Schengen visa waivers. All nationalities covered by this study are, in general, subject to visa requirements for travel to Ireland, and, in some cases, also subject to transit visa requirements. Even for those nationalities who can avail of the Irish Short Stay Visa Waiver Programme (Bosnia and Herzegovina, Montenegro, Serbia and Ukraine), this benefit is based on having a UK visa and having passed UK immigration control prior to travel to Ireland.

In the case of Georgia, however, Schengen visa liberalisation did coincide with a very noticeable increase in asylum applications and refusals of entry at the border. This has been a factor in a range of policy responses, including the introduction of a transit visa requirement in June 2017, and the inclusion of Georgia on the safe country of origin list in April 2018. Ukraine was also added to the transit visa list as a preventative measure.

In the case of Albania, while asylum flows and refusals of entry have increased significantly, a temporal link to the introduction of Schengen visa liberalisation is not so apparent, with the rise in asylum flows having begun some years following the introduction of visa liberalisation. Albania is also included on Ireland's safe country of origin list, but in this case while increased asylum flows were a factor in this decision, Schengen visa liberalisation was not.

There is no discernible impact of Schengen visa liberalisation on economic migration or tourism in Ireland. While there are some small levels of migration for remuneration reasons and study from nationals of countries with Schengen visa waivers, these are not significant as a proportion of the total number of thirdcountry nationals arriving in Ireland for such reasons. The Irish Short Stay Visa Waiver Programme, under which four of the countries are included, was introduced to promote tourism. While successful, its success has been largely attributed to tourism by Chinese nationals, and statistics on tourism from the nationals covered by the study are not available due to sample size and statistical confidentiality. 



\section{REFERENCES}

Beruchashvili, T. (2015). 'Removing EU visa requirements for Georgians would signal important change', The Irish Times, 20 May 2015, available at https://www.irishtimes.com/opinion/removing-eu-visa-requirements-forgeorgians-would-signal-important-change-1.2220084.

Coakley, L. (2015). Strengthening information and outreach for assisted voluntary return in Ireland, Dublin: International Organization for Migration, available at www.iom.int.

Council of the European Union (2017). 'Visas: Council adopts a revision of the visa waiver suspension mechanism', press release, 27 February 2017, available at www.consilium.europa.eu.

Department of Justice and Equality (2012). 'Minister Shatter announces extension of Irish Short-stay Visa Waiver Programme', press release, 12 March 2012, available at www.inis.gov.ie.

Department of Justice and Equality (2013a). 'Minister for Justice, Equality and Defence, Alan Shatter, TD, announces addition of Thailand to Visa Waiver Programme. Tourist and other short-stay visitor numbers likely to rise', press release, 14 November 2013, available at www.inis.gov.ie.

Department of Justice and Equality (2013b). 'Minister Shatter welcomes success of Visa Waiver Programme', press release, 4 July 2013, available at www.inis.gov.ie.

Department of Justice and Equality (2016). 'Tánaiste extends Irish Short Stay Visa Waiver Programme', press release, 14 October 2016, available at www.inis.gov.ie.

Department of Justice and Equality (2017). 'The need to address concerns regarding alleged people smuggling at Dublin Airport - Topical debate', press release, 24 January 2017, available at www.justice.ie.

Department of Justice and Equality (2019). 'Speech by Minister Flanagan on the Withdrawal of the United Kingdom from the European Union (Consequential Provisions) Bill 2019, 27 February 2019, available at www.justice.ie.

European Commission (2017). First Report under the visa suspension mechanism, $\operatorname{COM}(2017) 815$ final, available at https://ec.europa.eu/home-affairs/sites/homeaffairs/files/what-isnew/news/20171220_first_report_under_suspension_mechanism_en.pdf.

European Commission (2018a). 'Questions and answers: Adapting the common EU visa policy to new challenges', European Commission Fact Sheet, 14 March 2018, available at http://europa.eu/rapid/press-release.

European Commission (2018b). Second report under the visa suspension mechanism, $\operatorname{COM}(2018) 856$ final, available at https://ec.europa.eu/home-affairs/sites/homeaffairs/files/what-wedo/policies/european-agenda-migration/20181219_com-2018-856report_en.pdf. 
European Commission (2018c). 'Visa liberalisation: Commission reports on fulfilment of visa-free requirements by Western Balkans and Eastern Partnership countries', press release, 19 December 2018, available at http://europa.eu/rapid/pressrelease.

European Commission (2018d). 'Report on the fulfilment of visa-free requirements: Questions and answers', European Commission fact sheet, 19 December 2018, available at http://europa.eu/rapid/press-release.

European Migration Network (EMN) (2018a). Annual report on migration and asylum 2017: Statistical annex, Brussels: European Migration Network.

European Migration Network (EMN) (2018b). Asylum and migration glossary 6.0, Brussels: European Migration Network.

European Migration Network (EMN) (2019). Impact of visa liberalisation on countries of destination - Synthesis report for the EMN study, March 2019, available at www.emn.ie.

Immigration Enforcement (2018). 'Charges in suspected people smuggling investigation', press release, 29 June 2018, available at https://www.gov.uk/government/news/charges-in-suspected-people-smugglinginvestigation.

Irish Naturalisation and Immigration Service (INIS) (2016a). The Irish Short-stay Visa Waiver Programme: Information note - October 2016, available at: www.inis.gov.ie.

Irish Naturalisation and Immigration Service (INIS) (2016b). Immigration in Ireland: Annual review 2015, available at www.inis.gov.ie.

Irish Naturalisation and Immigration Service (INIS) (2017). Immigration in Ireland: Annual review 2016, available at www.inis.gov.ie.

Irish Naturalisation and Immigration Service (INIS) (2018). Immigration in Ireland: Annual review 2017, available at: www.inis.gov.ie.

Joint Oireachtas Committee on Foreign Affairs and Trade, and Defence (2018). Parliament of Georgia Foreign Relations Committee, 29 March 2018, available at www.oireachtas.ie.

Lally, C. (2018). 'Suspected people smugglers arrested after scam to enter Britain illegally via Ireland', The Irish Times, 29 June 2018, available at https://www.irishtimes.com/news/crime-and-law/suspected-people-smugglersarrested-after-scam-to-enter-britain-illegally-via-ireland-1.3547532.

Quinn, E. (2011). Visa policy as migration channel: Ireland, European Migration Network, Dublin: Economic and Social Research Institute, available at www.emn.ie and www.esri.ie.

Sheridan, A. (2017). Annual report on migration and asylum 2016: Ireland, European Migration Network, Dublin: Economic and Social Research Institute.

Sheridan, A. (2018). Annual report on migration and asylum 2017: Ireland, European Migration Network, Dublin: Economic and Social Research Institute. 

EMN Ireland,

Economic and Social

Research Institute,

Whitaker Square,

Sir John Rogerson's Quay,

Dublin 2, Ireland

Telephone +35318632000

Email emn.ireland@esri.ie

Web www.emn.ie / www.esri.ie

Twitter @EMNIreland

ISBN: 978-0-7070-0497-6 